\title{
The Lages diatremes: mineral composition and petrological implications
}

\author{
GIANCARLO BARABINO ${ }^{1}$, CELSO B. GOMES ${ }^{2}$ and GIANBOSCO TRAVERSA ${ }^{1,3}$ \\ ${ }^{1}$ Dipartimento di Scienze della Terra, Università di Roma "La Sapienza”, P. le Roma 5, 00185 Roma, Italia \\ ${ }^{2}$ Instituto de Geociências, Universidade de São Paulo, Rua do Lago 562, 05508-080 São Paulo, SP, Brasil \\ ${ }^{3}$ Istituto di Geoscienze e Georisorce, CNR, c/o Dipartimento di Scienze della Terra \\ Università di Roma “La Sapienza” P. le Roma 5, 00185 Roma, Italia
}

Manuscript received on April 24, 2006; accepted for publication on November 11, 2006; contributed by CELSO B. GOMES*

\begin{abstract}
Chemical data of heavy minerals from Lages diatremes in southern Brazil have been studied with the aim of characterizing the sample source(s). Three groups of minerals are recognized: I) aluminian-chromian pyroxene, pyrope garnet and chromian spinel, which represent disaggregated fragments of spinel, spinel+garnet and garnet facies peridotite; II) low-Cr aluminian pyroxene that occurs as megacrysts are high pressure phases (7-12 kb) being crystallized from an alkaline-like evolving magma; III) low-Cr aluminian diopside of crustal origin. Evidence of carbonatitic cryptic metasomatic enrichment is shown by clinopyroxenes of Groups I and II. The data do not support a kimberlitic affinity as it has been suggested for the diatremes. Rather, they are interpreted as vents related to the alkaline magmatism affecting the area in Late Cretaceous. The alkaline parental magma of the pyroxene megacrysts was generated from a metasomatized mantle at garnet facies that incorporated fragments of the surrounding still fertile mantle. Presumably at spinel-facies level the magma began to fractionate the megacrysts, whose crystallization proceeded over a large range of falling pressure and temperature. The chemical similarities between Group III clinopyroxenes and those from the differentiated lithotypes indicate that the magma carried this mineral phase on its evolution, at crustal conditions, towards a more evolved alkaline composition. Still, a non-cognate origin for the Group III clinopyroxenes cannot be discarded.
\end{abstract}

Key words: Brazil, mantle, clinopyroxene, megacryst, metasomatism.

\section{INTRODUCTION AND GEOLOGICAL BACKGROUND}

The alkaline magmatic suites of southern Brazil (Fig. 1A) are generally associated with carbonatites and rare kamafugitic, kimberlitic and other ultrapotassic rocktypes, showing tectonic control that started in the Early Cretaceous times with the continental break-up and drift (Herz 1977, Ulbrich and Gomes 1981, Gomes et al. 1990, Morbidelli et al. 1995, Comin-Chiaramonti and Gomes 2005). Notably, alkaline and alkaline-carbonatitic magmatisms are coeval with the Paraná flood volcanism (mainly at 132-133 Ma, range 136-127 Ma; Renne

\footnotetext{
*Member Academia Brasileira de Ciências Correspondence to: Celso de Barros Gomes E-mail: cgomes@usp.br
}

et al. 1992, Turner et al. 1994, Stewart et al. 1996) and related to the opening of the South Atlantic Ocean (Piccirillo and Melfi 1988).

The southern Brazilian alkaline occurrences display two main structural distribution patterns at the border of the Paraná basin, following in general 1) a NE-trending belt parallel to the shore-line between the São Paulo and Rio de Janeiro States and 2) an approximately WNWESE-trending (Cabo Frio Magmatic Lineament, cf. Riccomini et al. 2005). Moreover, the alkaline magmatism has been tectonically controlled by lineaments, arches, flexures, fault and rift zones (Riccomini et al. 2005) all active at least since the Early Mesozoic and probably up to the present day (cf. Berrocal and Fernandez 1996). 
Radiometric ages (Gomes at al. 1990, Morbidelli et al. 1995) show three main episodes of alkaline magmatic activity in the Brazilian Platform: at about $130 \mathrm{Ma}$ (e.g. Jacupiranga, Juquiá, Anitápolis occurrences), at 80-70 Ma (e.g. Alto Paranaíba, Rio Verde-Iporá, Poços de Caldas, Lages occurrences) and less than $65 \mathrm{Ma}$ (e.g. Cabo Frio occurrence). In this context, diatremes of ultrapotassic affinity associated with peridotitic rocks are widespread mainly in the Alto Paranaíba region (i.e. kimberlites and kamafugites; Svisero 1995, Bizzi et al. 1993, Gomes and Comin-Chiaramonti 2005), but some rare occurrences have also been described in the Santa Catarina State (Lages district; cf. L.F. Scheibe, unpublised data, Scheibe and Svisero 1988, Scheibe et al. 2005). In particular, information about kimberlitic diatremes from that district is scarce and restricted to the occurrences here investigated.

In general terms, mineral concentrates constitute an important source of information and sometimes may provide data that could be more difficult to obtain directly from xenolith suites. As a matter of fact, each mineral grain is, at least in principle, representative of a single xenolith, and analyses of most of them may provide at least statistical approaches to define both the source from where they have been derived and their petrological history.

In Brazil, peridotitic xenoliths are reported in various kimberlitic outcrops. Although they are mostly composed of fragments of garnet peridotite (Svisero et al. 1977, Meyer and Svisero 1987, Leonardos et al. 1993, Gibson et al. 1995, J.B. Carvalho, unpublished data, Costa et al. 2003, Mdludlu et al. 2003, Read et al. 2004), nodules of spinel peridotite have been found in some diatremes in the Minas Gerais State (Alto Paranaíba Igneous Province: APIP; Svisero et al. 1984, J.B. Carvalho, unpublished data, Gaspar et al. 2003, Read et al. 2004) and also associated with kamafugites from the alkaline province of Goiás, near to the boundary between the Paraná basin and the Neoproterozoic Brasília mobile belt (Gaspar et al. 2003). The finding of spinel peridotite and the scarcity of garnet peridotite among the mantle xenoliths of the APIP have led some authors to propose a shallow mantle source for the magmatic rocks outcropping in the area (Bizzi et al. 1993, Meyer et al. 1993). However, Leonardos et al. (1993) have identified xenoliths of fertile peridotite in the Três Ranchos kimberlite in the Minas Gerais State. These various types of xenoliths indicate that the outcropping magmatic rocks have been derived from separate mantle sources of different depths (Gibson et al. 1995, Araújo et al. 2001, Gaspar et al. 2003).

This study describes the heavy mineral concentrates from the Janjão, Pandolfo and Lambedor diatremes, near the city of Lages in the Santa Catarina State. The analyzed minerals (clinopyroxenes, garnets, chromian spinels and ilmenites) represent residual phases after extensive weathering. It has a twofold purpose: firstly, to investigate with more detail the supposed kimberlitic nature of the Janjão, Pandolfo and Lambedor diatremes; and secondly, to obtain information about the source from which the collected minerals have been originated. Our overall objective is to highlight the links between the Cretaceous alkaline volcanic rocks, which constitute the Lages alkaline district, and the lithospheric upper mantle underlying the area.

\section{THE LAGES ALKALINE DISTRICT}

The Lages intrusion (Fig. 1B) outcrops over an area of $\sim 50 \mathrm{~km}^{2}$ and it is located about $100 \mathrm{~km}$ east of Anitápolis, another alkaline occurrence in the Santa Catarina State. The magmatic suite is mainly composed of leucocratic rocks (peralkaline phonolites and minor phonotephrites and nepheline syenites) with subordinate mafic-ultramafic rocks (olivine melilitites, olivine nephelinites and minor basanites), Fe-carbonatites, diatreme kimberlite-like breccias (Scheibe 1978, L.F. Scheibe, unpublished data, Traversa et al. 1994, 1996, Gibson et al. 1999, Comin-Chiaramonti et al. 2002) and rare minettes (Gibson et al. 1999).

The suite has been emplaced into the eastern margin of the Paraná basin, associated with the uplift of a large crustal block (the "Lages Dome", cf. Paiva 1933). The dome is underlined by a concentric arrangement of Permian to Triassic sediments and it is tectonically controlled by an old NW-trending fault zone (L.F. Scheibe, unpublished data, Traversa et al. 1994). The igneous rocks occur as shallow intrusions, pipe breccias and dykes throughout the dome structure. They display a roughly annular distribution, but are mainly concentrated along a $10 \mathrm{~km}$ wide, $\mathrm{N} 60^{\circ}$ E-trending belt, in the eastern 
part of the district (Traversa et al. 1994).

Although in that region the basement is covered by thick sedimentary sequences, Mantovani et al. (1991), relying on geophysical evidence, suggest that the volcanic field has been emplaced at the contact between the Rio de La Plata-Luis Alves craton and the Dom Feliciano Proterozoic mobile belt. K/Ar data indicate a Late Cretaceous age ranging from $68 \mathrm{Ma}$ (Amaral et al. 1967, Sonoki and Garda 1988) to $76 \mathrm{Ma}$ (Gibson et al. 1999). $\mathrm{A} \mathrm{Rb} / \mathrm{Sr}$ whole-rock errorchron yielded an age of $82 \pm$ $6 \mathrm{Ma}$ (cf. Scheibe et al. 1985).

According to some authors (Thompson et al. 1998, Gibson et al. 1995, 1999), the Lages alkaline magmatism was caused by the "post-impact" extension of the Trindade mantle plume head. The center of the plume in the Late Cretaceous (85 Ma) was about $1000 \mathrm{~km}$ north of the Lages area and because of a mechanism of southward channeling of high temperature melts, distant from the thick keels of the São Francisco craton, it gave rise to the Late Cretaceous melting of the sublithospheric mantle of southern Brazil. However, according to CominChiaramonti et al. (2002), this model does not take into consideration other Late Cretaceous alkaline occurrences as those outcropping e.g. in the Piratini district (south Brazil) or even in Paraguay. Thus, Comin-Chiaramonti et al. (2002) discarded the plume activity and, following Smith and Lewis's model (1999), suggested that the intraplate alkaline and alkaline-carbonatitic magmatism of southern Brazil should be related to decompression and melting of the variously metasomatized portions of the lithospheric mantle which occurred where second order sutures (e.g. Rio Uruguay and Piquiri lineaments) intersect the axis of a major rifting, the latter being parallel to pre-existing N-S sutures.

\section{THE DIATREMES}

About 35 occurrences, i.e. diatremes, pipe breccias and brecciated dikes have been identified in the Lages area (L.F. Scheibe, unpublished data, Scheibe et al. 2005 and therein references), cutting across the Permo-Cretaceous sedimentary formations, varying in size from about 30 to $150 \mathrm{~m}$. The diatremes are characterized by angular fragments of different lithologies (carbonatite, nepheline syenite, leucitite, basaltic tholeiite and very rare dunite) and minerals (diopside, garnet, phlogopite, magnetite, ilmenite and zircon) of various origins set in a strongly altered groundmass.

The Janjão diatreme is located about $8 \mathrm{~km} \mathrm{NE}$ of Lages, at the village of Guarajá, and nowadays forms an oval depression measuring $50 \times 190 \mathrm{~m}$. The Pandolfo diatreme is found at the locality of Pandolfo, about $3 \mathrm{~km}$ $\mathrm{W}$ of Lages. The Lambedor intrusion outcrops about $20 \mathrm{~km}$ E of that town; it shows a roughly circular shape and it is about $100 \mathrm{~m}$ in diameter.

The strong altered groundmass did not allow suitable thin sections. Thus, the studied minerals represent the heavy phases that survived the weathering processes. Pyroxenes and garnets represent the more abundant phases of the mineral samples, with very subordinate ilmenites and chromian spinels (Barabino et al. 2003). According to L.F. Scheibe, unpublished data, no diamonds were found in any heavy mineral separates, although their presence is reported by the "garimpeiros" (prospectors and diggers) working in the area.

A kimberlitic affinity for the Janjão, Pandolfo and Lambedor diatremes (Fig. 1B) was previously suggested by L.F. Scheibe, unpublished data, Svisero et al. (1985) and Scheibe and Svisero (1988) on the basis of crystallochemical and geophysical evidence.

\section{ANALYTICAL METHODS}

All analyzed minerals have been hand-picked from concentrates and selected on the basis of the morphological characteristics, i.e. unaltered fresh surfaces. All separates were leached with diluted $\mathrm{HCl}$, washed with distilled water and subjected to ultrasonic vibration. The grains were fixed on epoxy resin and polished for microprobe analysis.

Major element concentrations were measured using a fully automated Cameca SX 50 microprobe at the CNR "Istituto di Geologia Ambientale e Geoingegneria" laboratories of the University of Rome "La Sapienza". Analytical conditions were as follows: $15 \mathrm{kV}$ acceleration potential; 15 nA beam current; 10-30" counting time, as a function of the analyzed element. Silicate minerals and synthetic oxides were employed as standards.

The concentrations of trace elements and REE of clinopyroxenes were measured at the Activation Laboratories L.T.D., Canada, by ICP-MS techniques. Analyses were performed on powders obtained from selected crys- 

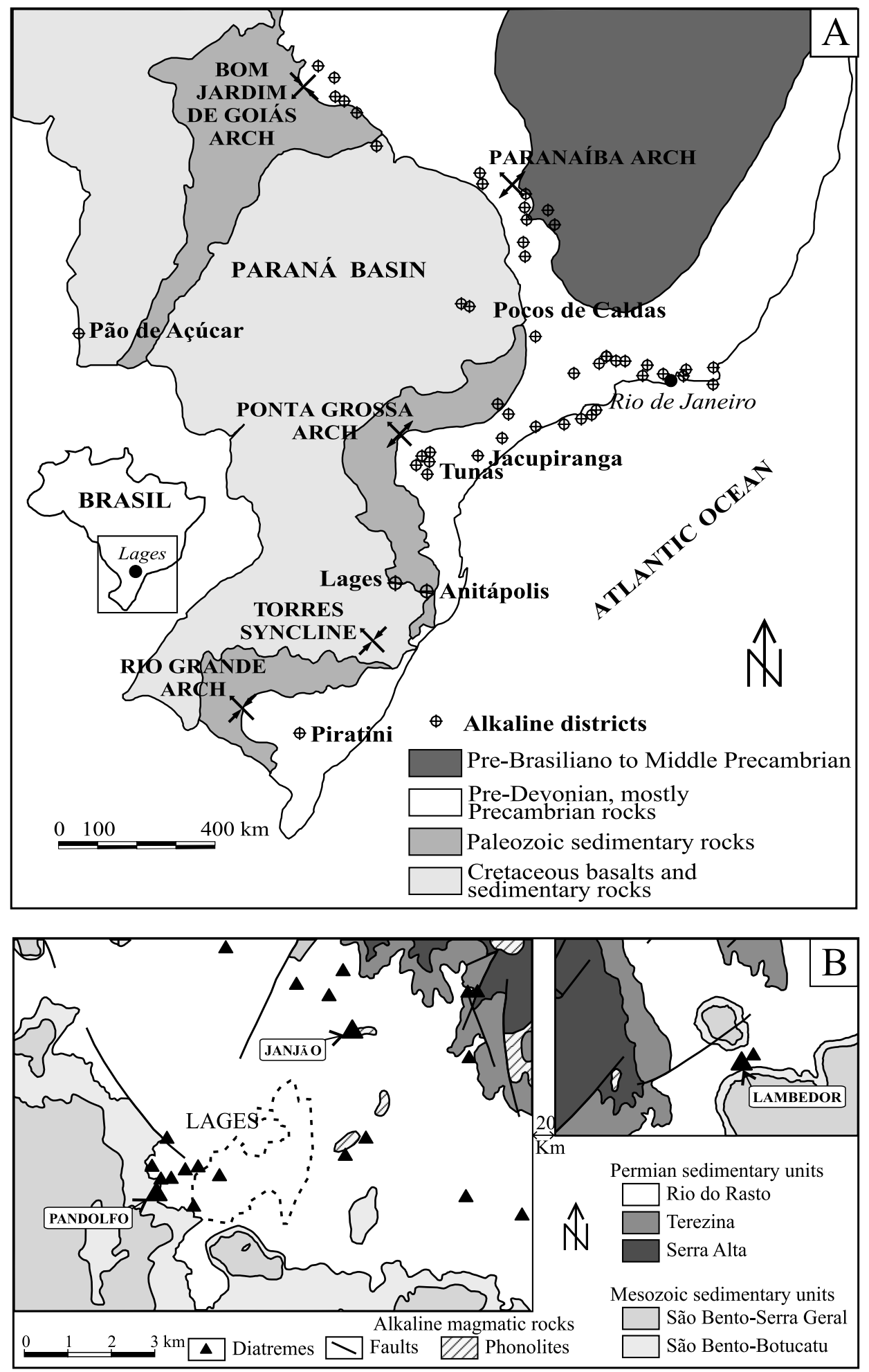

Fig. 1 - A) Sketch-map of the alkaline districts of southern Brazil (after Traversa et al. 1996); B) simplified geological map of the Lages occurrence showing the location of the diatremes of Janjão, Pandolfo and Lambedor (after L.F.Scheibe, unpublished data, modified). 
tals whose major chemistry was controlled by preliminary microprobe investigation. Lower limits of detection were 0.01-0.02 ppm for $\mathrm{Cu}, \mathrm{Ga}, \mathrm{Y}, \mathrm{Nb}, \mathrm{Mo}, \mathrm{Te}, \mathrm{Pb}$ and Ce; 0.05 ppm for Sn and Ta; 0.1 ppm for Li, Co, Ge, Rb, $\mathrm{Zr}, \mathrm{Hf}, \mathrm{Th}, \mathrm{Nd}, \mathrm{Sm}, \mathrm{Eu}, \mathrm{Tb}$ and $\mathrm{Yb} ; 0.5 \mathrm{ppm}$ for Be, Sr, $\mathrm{Ba}$ and $\mathrm{La} ; 1$ ppm for $\mathrm{V}$.

VCell and VM1 of clinopyroxenes were calculated using the Excel version of "CpxBar" (Nimis and U1mer 1998), a computer program that, using electron microprobe data, simulates clinopyroxene structure allowing the calculation of the cell parameters without single crystal X-rays diffraction analyses.

\section{MINERAL COMPOSITION}

Representative microprobe analyses of pyroxenes are given in Tables Ia-c; those of garnets and chromitesilmenites are listed in Tables II and III, respectively.

\section{Clinopyroxenes}

The clinopyroxenes range between 1 and $20 \mathrm{~mm}$ in size. The grains usually show clear and transparent surfaces without spongy rims and/or orthopyroxene and/or ilmenite exsolutions. Only in a few cases the edges are coated by a few microns weak film of polycrystalline aggregate of brownish alteration materials. Detailed microprobe analyses of major elements in representative crystals do not show important chemical zoning but only minor core-rim compositional variations.

Typological and geochemical criteria allowed us to distinguish three main groups:

Group I: low-Cr aluminian augite $\left[4.96<\mathrm{Al}_{2} \mathrm{O}_{3}\right.$ $<7.14 ; \mathrm{Cr}_{2} \mathrm{O}_{3}<0.13 ; 0.78<\mathrm{Mg}_{\text {cpx }}<0.85 ; \mathrm{Mg}_{\text {cpx }}=$ $\mathrm{Mg} /(\mathrm{Mg}+\mathrm{Fe})]$, deep green to black in color. The largest crystals $(20 \mathrm{~mm}>\varnothing>10 \mathrm{~mm}$ ) occur as subeuhedral grains, rarely sub-rounded, whereas the smallest ones ( $1 \mathrm{~mm}<\varnothing<2 \mathrm{~mm}$, generally fragments of the latter) usually show anhedral shape. On the whole, they exhibit conchoidal fracture and glassy luster on freshly broken surfaces. These clinopyroxenes tend to plot into the lamproite field of Fig. 2A.

Group II: aluminian-chromian diopside and augite $\left[4.07<\mathrm{Al}_{2} \mathrm{O}_{3}<7.10 ; 0.63<\mathrm{Cr}_{2} \mathrm{O}_{3}<1.80 ; 0.85<\mathrm{Mg}_{\text {cpx }}\right.$ $<0.92$ ], green in color. The crystals range between 1 and $2 \mathrm{~mm}$ in diameter and show subeuhedral to anhedral habit. Compositionally, they plot near to the fields of kimberlite analogues and of granular lherzolites and $\mathrm{Cr}$ rich megacrysts in kimberlites (Figs. 2A, B); they partially overlap the field of clinopyroxenes of peridotites from alkali basaltic-like magmas.

Group III: low-Cr aluminian diopside $\left[3.34<\mathrm{Al}_{2} \mathrm{O}_{3}<\right.$ 7.52; $\mathrm{Cr}_{2} \mathrm{O}_{3}<0.13 ; 0.68<\mathrm{Mg}_{\text {cpx }}<0.72$ ], dark greenish in color. The crystals, usually subeuhedral, range between 1 and $2 \mathrm{~mm}$ in diameter and plot in the field representing the Lages intermediate alkaline rocks (phonotephrites to nepheline syenites, Fig. 2C).

All the analyzed clinopyroxenes are relatively rich in $\mathrm{Al}_{2} \mathrm{O}_{3}$ (Fig. 3). From a general compositional point of view, Groups I and II tend to fit into an intermediate field between kimberlites and lamproites (Fig. 2A). The Group II minerals fit into the field of clinopyroxenes of spinel-, spinel+garnet- and garnet peridotites from alkali basaltic-like magmas (Fig. 3), and partially overlap the field of clinopyroxenes of spinel peridotites from Premier kimberlites. With increasing $\mathrm{Mg}_{\text {cpx }}$ (Fig. 4), the Group I clinopyroxenes show negative correlation with $\mathrm{Ti}$ and $\mathrm{Na}$, whereas Al is generally scattered. The Group II minerals have similar trends regarding $\mathrm{Ti}$, and $\mathrm{Cr}$ is positively correlated whereas $\mathrm{Na}$ is scattered. Finally, the Group III clinopyroxenes, which show the highest Ca, $\mathrm{Na}$ and $\mathrm{Ti}$ contents, does not show evident correlations with $\mathrm{Mg}_{\mathrm{cpx}}$.

In terms of $\mathrm{Mg}_{\text {cpx }}$ vs. $\mathrm{Ca}_{\text {cpx }}\left[\mathrm{Ca}_{\mathrm{cpx}}=\mathrm{Ca} /(\mathrm{Ca}+\mathrm{Mg})\right.$; Fig. 4] the three groups of minerals display different features. The Group III clinopyroxenes form a cluster on the upper-right side of the diagram, showing a compositional gap in comparison with the other groups. The Group I exhibits a well-defined linear negative trend whereas the Group II show only a weak negative correlation.

Differences among Groups I and II, on one hand, and Group III minerals, on the other, are also apparent from VCell and VM1 crystallographic clues (Fig. 5). In general, with increasing pressure, the minerals tend to change the cell parameters (cf. Dal Negro et al. 1984, 1989, Princivalle et al. 1989, 1995, 2000, Nimis 1995): clinopyroxenes crystallized at higher pressure are characterized by lower VCell and VM1 values. Nevertheless, the VCell and VM1 relations may depend on several variables such as bulk composition and temperature (Dal Negro et al. 1984, 1989, Nimis 1995, Nimis and 


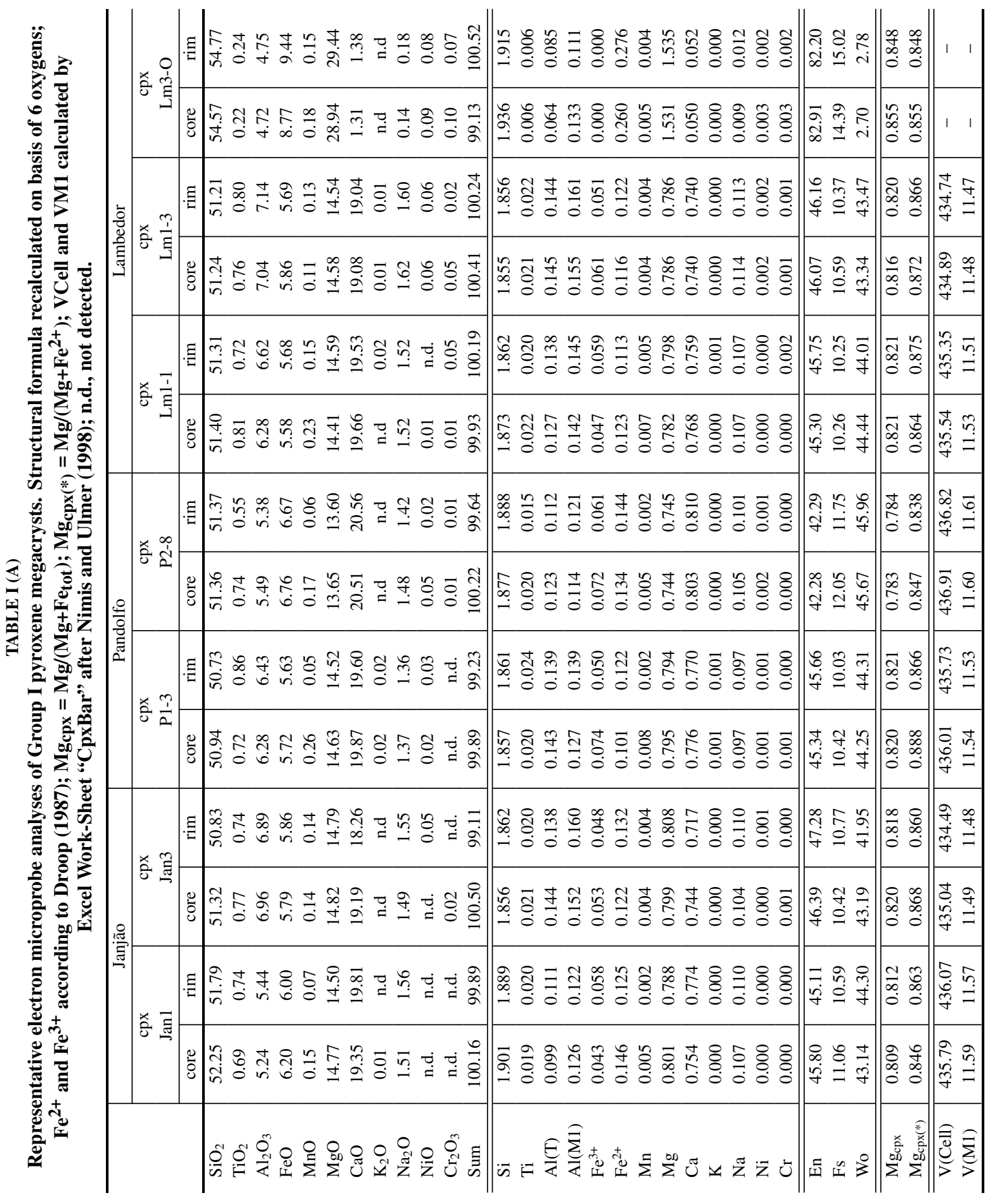




\begin{tabular}{|c|c|c|c|c|c|c|}
\hline & 峞总 & 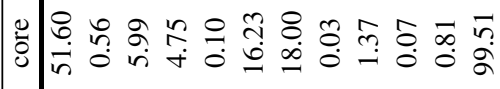 & 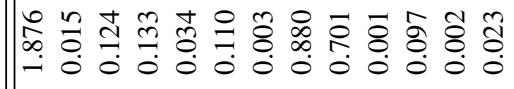 & 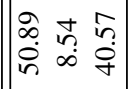 & $\left.\mid \begin{array}{ccc}a & a \\
0 & 0 \\
0 & 0 \\
0 & 0 & 0\end{array}\right]$ & 色 \\
\hline & & 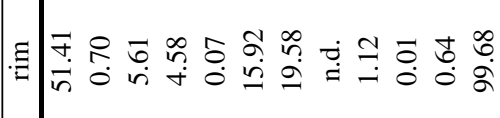 & 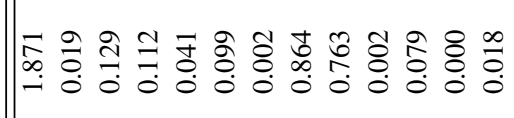 & 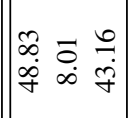 & $\mid \begin{array}{lll}\overrightarrow{0} & \infty \\
\infty & 0 \\
0 & 0 \\
0 & 0 \\
0\end{array}$ & 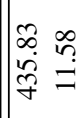 \\
\hline j & 罗 & 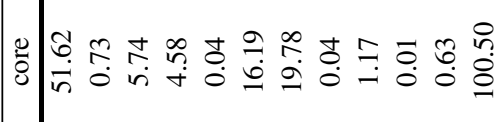 & 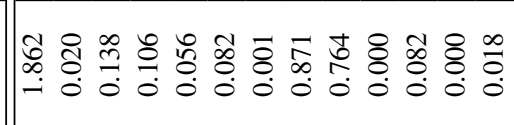 & 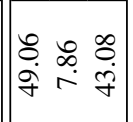 & 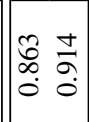 & 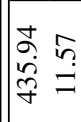 \\
\hline 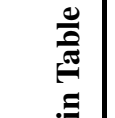 & 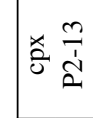 & 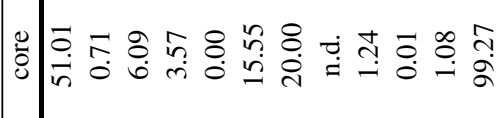 & 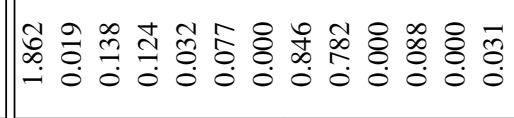 & 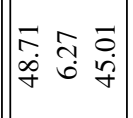 & $\mid \begin{array}{ll}\infty & 0 \\
\infty & 0 \\
0 & 0 \\
0 & 0\end{array}$ & 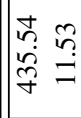 \\
\hline 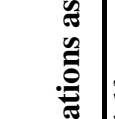 & 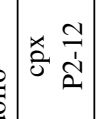 & 品 & 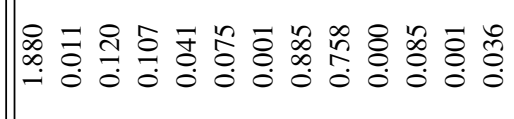 & 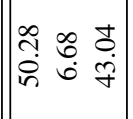 & 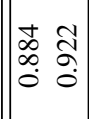 & 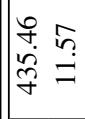 \\
\hline 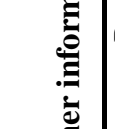 & 돔 & 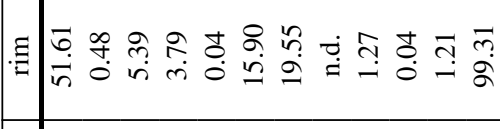 & 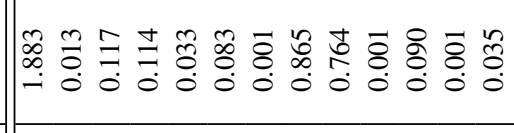 & 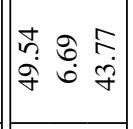 & $\| \begin{array}{ll}0 & 2 \\
\infty & 2 \\
0 & 0 \\
0 & 0\end{array}$ & 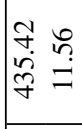 \\
\hline$\overline{\overline{0}}$ & & 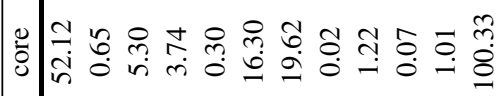 & 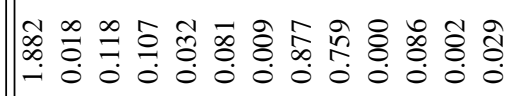 & $\| \begin{array}{lll}a & n & 0 \\
a & a & 0 \\
\dot{q} & b & \dot{g}\end{array} \mid$ & $\mid \begin{array}{ll}0 & n \\
\infty & 0 \\
0 & a \\
0 & 0\end{array}$ & $\begin{array}{ll}n \\
n \\
n & n \\
y & n \\
y & =1\end{array}$ \\
\hline t) & 0 & 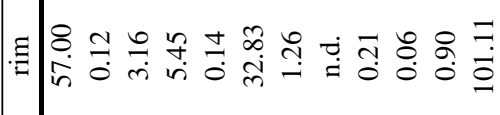 & 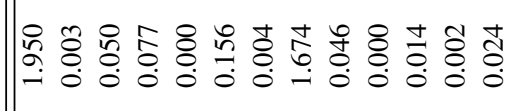 & 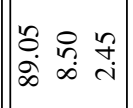 & $\| \begin{array}{ll}n & n \\
\bar{a} & \cdots \\
0 & 0 \\
0 & 0\end{array}$ & 11 \\
\hline 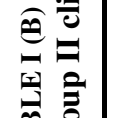 & $\overline{\bar{y}}$ & 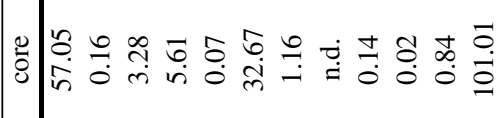 & 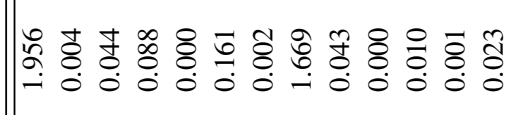 & 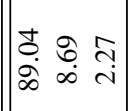 & 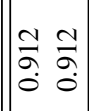 & 11 \\
\hline to & त & 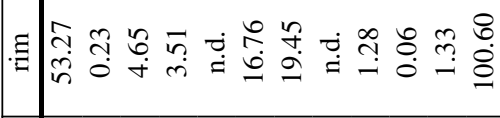 & 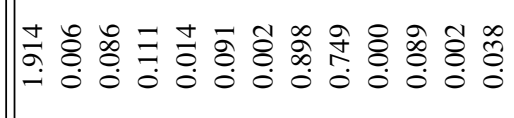 & 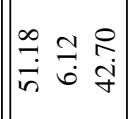 & $\| \begin{array}{ll}n & \infty \\
0 & 0 \\
0 & 0 \\
0 & 0 \\
0\end{array}$ & 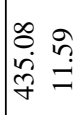 \\
\hline 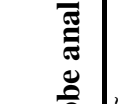 & 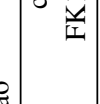 & 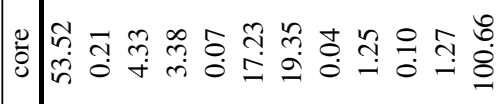 & 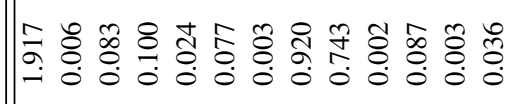 & $\left|\begin{array}{ccc}\partial & a & 0 \\
i & \infty & 0 \\
i & i & i \\
i\end{array}\right|$ & $\mid$\begin{tabular}{|l|l|}
$\overrightarrow{0}$ & $\tilde{2}$ \\
0 & 0 \\
0 & 0
\end{tabular} & 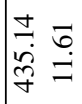 \\
\hline : & $\vec{\lambda}$ & 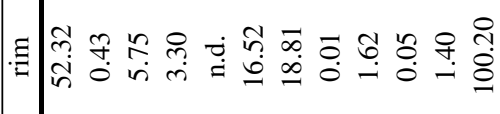 & 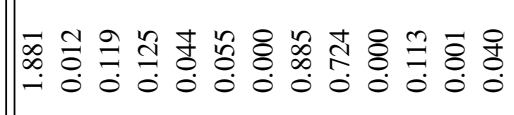 & 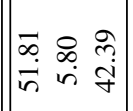 & 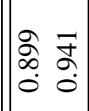 & 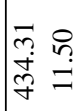 \\
\hline 莺 & $5-$ & 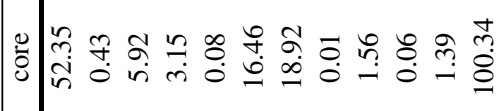 & 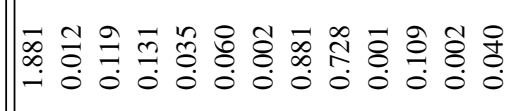 & 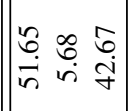 & $\mid \begin{array}{ll}\infty & 0 \\
\hat{2} & 0 \\
0 & 0 \\
0 & 0\end{array}$ & 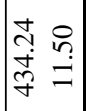 \\
\hline 离 & $\star \dot{d}$ & 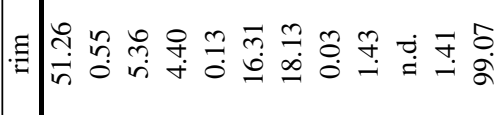 & 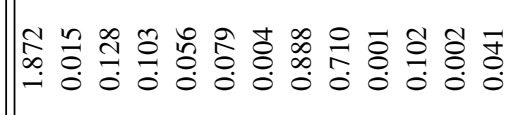 & 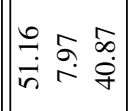 & 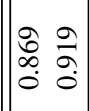 & 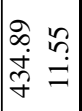 \\
\hline & & 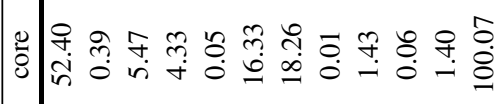 & 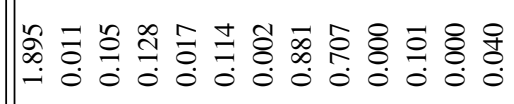 & 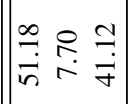 & 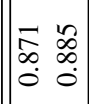 & 点 \\
\hline & & 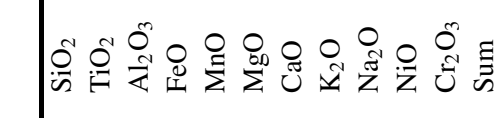 & $E \sum_{-=}^{E}+$ & & $\mid \sum^{\infty}$ & $\stackrel{\overline{\bar{U}}}{>} \sum_{>}^{\bar{z}}$ \\
\hline
\end{tabular}


TABLE I (C)

Representative electron microprobe analyses of Group III clinopyroxenes. Other informations as in Table $1 \mathrm{~A}$.

\begin{tabular}{|c|c|c|c|c|c|c|}
\hline & \multirow{2}{*}{\multicolumn{2}{|c|}{$\begin{array}{c}\text { Pandolfo } \\
\text { cpx } \\
\text { P2-9 }\end{array}$}} & \multicolumn{4}{|c|}{ Lambedor } \\
\hline & & & \multicolumn{2}{|c|}{$\begin{array}{c}\text { cpx } \\
\text { Lm2-3 }\end{array}$} & \multirow{2}{*}{$\begin{array}{c}\text { cpx } \\
\text { Lm2-6 }\end{array}$} & \multirow{2}{*}{$\begin{array}{c}\text { cpx } \\
\text { Lm2-9 }\end{array}$} \\
\hline & core & rim & core & rim & & \\
\hline $\mathrm{SiO}_{2}$ & 50.45 & 50.31 & 53.28 & 53.52 & 49.69 & 48.86 \\
\hline $\mathrm{TiO}_{2}$ & 0.65 & 0.66 & 0.43 & 0.49 & 0.83 & 1.39 \\
\hline $\mathrm{Al}_{2} \mathrm{O}_{3}$ & 5.94 & 6.06 & 3.34 & 3.60 & 5.64 & 7.11 \\
\hline $\mathrm{FeO}$ & 9.08 & 9.24 & 5.41 & 5.86 & 8.78 & 7.95 \\
\hline $\mathrm{MnO}$ & 0.11 & 0.17 & 0.11 & 0.17 & 0.20 & 0.11 \\
\hline $\mathrm{MgO}$ & 10.89 & 10.93 & 13.53 & 13.20 & 11.39 & 11.66 \\
\hline $\mathrm{CaO}$ & 20.28 & 20.15 & 21.21 & 20.64 & 21.49 & 22.28 \\
\hline $\mathrm{K}_{2} \mathrm{O}$ & 0.02 & 0.05 & 0.05 & 0.04 & n.d. & n.d. \\
\hline $\mathrm{Na}_{2} \mathrm{O}$ & 2.28 & 2.20 & 2.20 & 2.38 & 1.56 & 1.17 \\
\hline $\mathrm{NiO}$ & 0.04 & 0.02 & n.d. & 0.04 & 0.03 & n.d. \\
\hline $\mathrm{Cr}_{2} \mathrm{O}_{3}$ & 0.01 & 0.02 & 0.02 & n.d. & n.d. & 0.03 \\
\hline Sum & 99.75 & 99.82 & 99.58 & 99.95 & 99.63 & 100.57 \\
\hline $\mathrm{Si}$ & 1.867 & 1.862 & 1.948 & 1.952 & 1.848 & 1.800 \\
\hline $\mathrm{Ti}$ & 0.018 & 0.018 & 0.012 & 0.013 & 0.023 & 0.039 \\
\hline $\mathrm{Al}(\mathrm{T})$ & 0.133 & 0.138 & 0.052 & 0.048 & 0.152 & 0.200 \\
\hline Al (M1) & 0.126 & 0.126 & 0.092 & 0.107 & 0.096 & 0.109 \\
\hline $\mathrm{Fe}^{3+}$ & 0.135 & 0.134 & 0.094 & 0.085 & 0.122 & 0.097 \\
\hline $\mathrm{Fe}^{2+}$ & 0.146 & 0.152 & 0.072 & 0.094 & 0.151 & 0.148 \\
\hline Mn & 0.003 & 0.005 & 0.003 & 0.005 & 0.006 & 0.004 \\
\hline $\mathrm{Mg}$ & 0.601 & 0.603 & 0.738 & 0.718 & 0.632 & 0.640 \\
\hline $\mathrm{Ca}$ & 0.804 & 0.799 & 0.831 & 0.806 & 0.857 & 0.880 \\
\hline K & 0.001 & 0.002 & 0.002 & 0.002 & 0.000 & 0.000 \\
\hline $\mathrm{Na}$ & 0.164 & 0.158 & 0.156 & 0.169 & 0.112 & 0.084 \\
\hline $\mathrm{Ni}$ & 0.001 & 0.001 & 0.000 & 0.001 & 0.001 & 0.000 \\
\hline $\mathrm{Cr}$ & 0.000 & 0.001 & 0.001 & 0.000 & 0.000 & 0.001 \\
\hline En & 35.57 & 35.61 & 42.46 & 42.02 & 35.74 & 36.20 \\
\hline Fs & 16.83 & 17.22 & 9.73 & 10.78 & 15.81 & 14.06 \\
\hline Wo & 47.59 & 47.17 & 47.81 & 47.20 & 48.45 & 49.74 \\
\hline $\mathrm{Mg}_{\mathrm{cpx}}$ & 0.681 & 0.678 & 0.817 & 0.801 & 0.698 & 0.723 \\
\hline $\operatorname{Mg}_{\operatorname{cpx}(*)}$ & 0.805 & 0.799 & 0.911 & 0.884 & 0.807 & 0.812 \\
\hline V (Cell) & 437.01 & 437.04 & 436.79 & 436.29 & 438.66 & 438.82 \\
\hline V (M1) & 11.55 & 11.56 & 11.63 & 11.61 & 11.65 & 11.61 \\
\hline
\end{tabular}




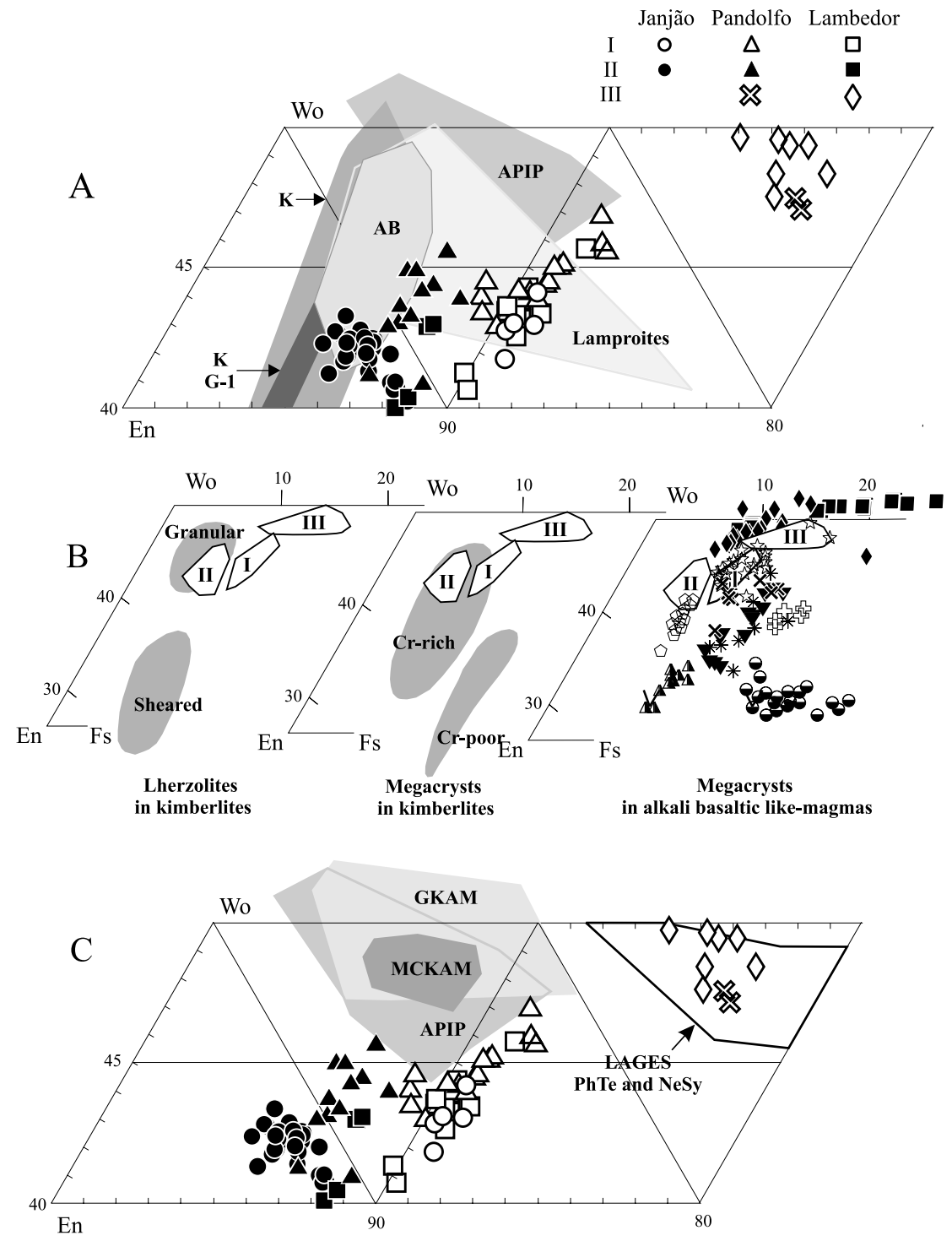

Fig. 2 - A) En-Wo-Fe ternary diagram for clinopyroxenes from the Janjão, Pandolfo and Lambedor diatremes (I, II, and III groups as after Table 1) compared with analogues from peridotite nodules from APIP pipes (Alto Paranaíba; Meyer and Svisero 1991, Meyer et al. 1991, Araújo et al. 2001), lamproites (Mitchell and Bergman 1991), kimberlites, K (Mitchell and Bergman 1991 and references therein), kimberlites, group I, K G-I (Franz et al. 1996, Davies et al. 2001) and alkali basalts, AB (Princivalle et al. 1989, 2000). B) I, II and III clinopyroxene groups from Lages compared with clinopyroxenes after Haggerty (1994 and references therein). Megacrysts from alkali basaltic-like magmas: asterisks after Irving (1974); half-filled circles, stars and pentagons after Schulze (1987) and therein references; open crosses after Dal Negro et al. (1989); axis after Nasir (1995); full squares after Dobosi and Jenner (1999); full rhombs after Shaw and Eyzaguirre (2000); inverted full triangles and half-filled triangles after Akinin et al. (2005). C) Comparison with the compositional fields of the clinopyroxenes from APIP, Mata da Corda and Goiás kamafugites (MCKAM and GKAM, respectively; Sgarbi et al. 2000 and references therein) and Lages phonoteprites and nepheline syenites (LAGES PhTe and NeSy; Traversa et al. 1994, 1996).

Ulmer 1998). The Group III clinopyroxenes generally show VCell and VM1 parameters higher than those of the Groups I and II clinopyroxenes and similar to those of clinopyroxene phenocrysts from tholeiitic to alkaline basaltic rocks (see Dal Negro et al. 1989). Notably, they are also in part similar with those pyroxenes from the 
mildly evolved rocks of the Lages district (cf. Traversa et al. 1994, 1996). This fact not only indicates a low pressure origin for the Group III clinopyroxenes but, also in view of chemical analogies (Fig. 2C), suggests that they could be components of the volcanic rocks cropping out in the area.

The Group I and II clinopyroxenes show clear differences in both morphological and crystallochemical features (Figs. 2 and 3). $\mathrm{Cr}_{2} \mathrm{O}_{3}, \mathrm{TiO}_{2}, \mathrm{MgO}$ and $\mathrm{FeO}$ contents and some inter-element variations (Fig. 4) point that they are not genetically related. Moreover, although VCell and VM1 cannot be totally discriminate between the two groups, in the VCell-VM1 space (Fig. 5) they outline two different, sub-parallel, trends as, at comparable VM1, the clinopyroxenes of the Group I that show higher VCell values.

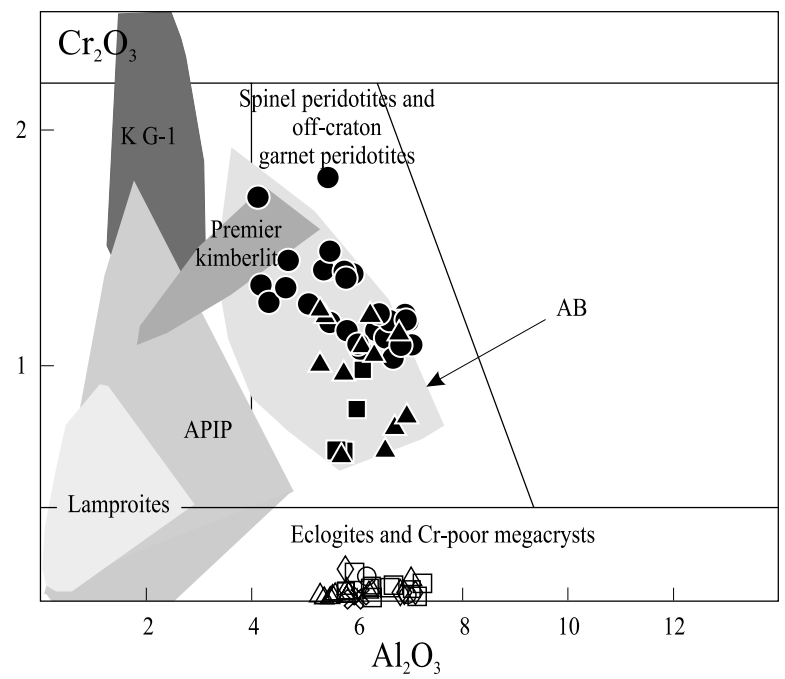

Fig. $3-\mathrm{Al}_{2} \mathrm{O}_{3}$ vs. $\mathrm{Cr}_{2} \mathrm{O}_{3}$ for clinopyroxenes from the Janjão, Pandolfo and Lambedor diatremes (after Nimis 1998, modified). 2. Premier kimberlites field after Grégoire et al. (2005). AB: clinopyroxenes from $\mathrm{Sp}$-, $\mathrm{Sp}+\mathrm{Grt}$ and Grt- peridotites from alkali basalt-like magmas after Princivalle et al. (1989, 2000), Ionov et al. (1993) and Kempton et al. (1999). Symbols and references as in Fig. 2.

The high $\mathrm{Mg}_{\text {cpx }}$ values combined with the $\mathrm{Cr}_{2} \mathrm{O}_{3}$ (Fig. 3) contents of the Group II clinopyroxenes are consistent with a derivation from peridotitic source. In the Fig. 2B, they fall in the field of the clinopyroxenes from granular peridotites, and almost completely overlap the field of the clinopyroxenes from the Cr-rich megacrysts (e.g. Schulze 1987, Moore and Belusova 2005).
Cr-rich minerals are found in both kimberlite and alkali magmas and consist of single large crystals of diopside, garnet, enstatite and olivine. In general, in terms of chemical composition, such minerals tend to overlap the fields of the analogous phases in granular and sheared lherzolites worlwide (Fig 2B, for clinopyroxenes). They are interpreted either to be genetically linked to the host magma (Moore and Belusova 2005) or to represent xenocrysts, unrelated to the host magma (Schulze 1987, Akinin et al. 2005). At Lages, the Group II clinopyroxenes are anhedral, and rarely subeuhedral small grains, and could represent fragments of larger grains but in the concentrates it was not found any single discrete crystals showing comparable chemical composition. So, although a potential affinity cannot be completely discarded, it is difficult to consider the Group II clinopyroxenes as members of the Cr-rich megacrysts suite. More probably they are fragments of disaggregated peridotite nodules.

The crystallochemical features of the Group I minerals are consistent with those of clinopyroxenes of the megacrystic Cr-poor suite (Schulze 1987, Hops et al. 1992, Mitchell 1989, 1995). This suite consists of single large monomineralic grains (or discrete nodules) of Cr-poor subcalcic clinopyroxene, Cr-poor enstatite, $\mathrm{Cr}$ poor titanian pyrope, magnesian ilmenite, subordinate phlogopite and zircon and possibly olivine commonly occurring, not necessarily together, in kimberlites and alkali-basalts. The Group I clinopyroxenes show both En-Wo-Fe relations (Fig. 2B) and $\mathrm{Al}_{2} \mathrm{O}$ and $\mathrm{TiO}_{2}$ contents similar to those of clinopyroxene megacrystals usually found in worldwide alkali basaltic-like magmas (e.g. Schulze 1987).

\section{ORTHOPYROXENES}

Orthopyroxenes are rare. The crystals range between 1 and $2 \mathrm{~mm}$ in size and are greenish in color. From a typological and crystallochemical point of view two different groups can be distinguished:

Group I: low-Cr aluminian enstatite $\left[4.96<\mathrm{Al}_{2} \mathrm{O}_{3}<\right.$ 7.10; $\left.\mathrm{Cr}_{2} \mathrm{O}_{3}<0.19 ; \mathrm{Mg}_{\text {opx }}=0.85 ; \mathrm{Mg}_{\text {opx }}=\mathrm{Mg} /(\mathrm{Mg}+\mathrm{Fe})\right]$. They are anhedral in shape and probably constitute fragments of larger crystals. On geochemical basis, they could represent members of the $\mathrm{Cr}$-poor megacrysts suite. Likewise Group I clinopyroxenes, the Group I orthopy- 


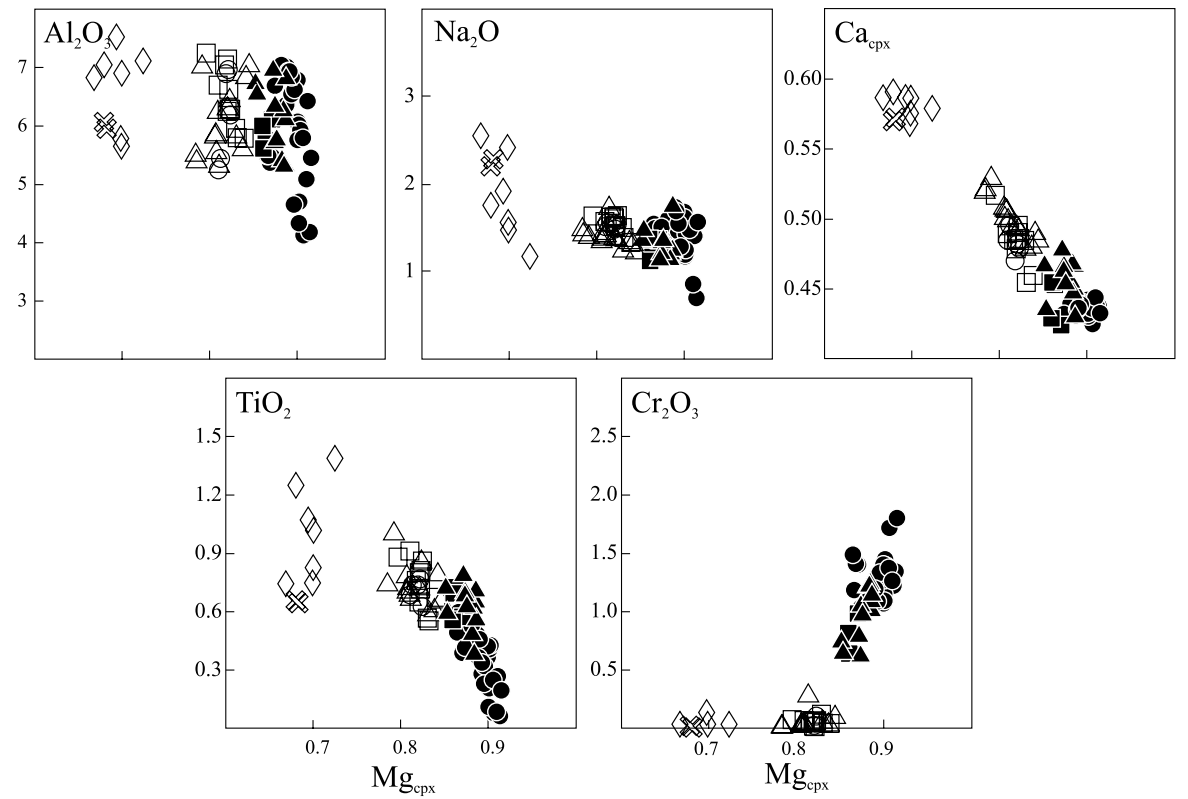

Fig. 4 - Variation of $\mathrm{Al}_{2} \mathrm{O}_{3}, \mathrm{TiO}_{2}, \mathrm{Na}_{2} \mathrm{O}, \mathrm{Cr}_{2} \mathrm{O}_{3}$ and $\mathrm{Ca}_{\text {cpx }}$ vs. $\mathrm{Mg}_{\text {cpx }}$ for clinopyroxenes from the Janjão, Pandolfo and Lambedor diatremes. $\mathrm{Mg}_{\mathrm{cpx}}=\mathrm{Mg} /(\mathrm{Mg}+\mathrm{Fe}) ; \mathrm{Ca}_{\mathrm{cpx}}=\mathrm{Ca} /(\mathrm{Ca}+\mathrm{Mg})$. Symbols as in Fig. 2 .

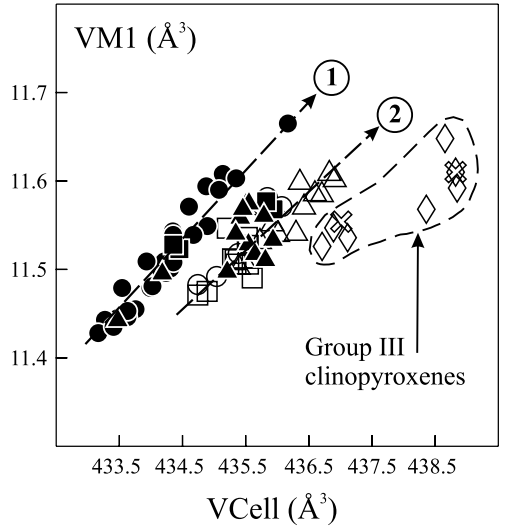

Fig. 5 - Variation of VCell vs. VM1 for clinopyroxenes from the Janjão, Pandolfo and Lambedor diatremes. 1 and 2: trend of clinopyroxenes that are thought to have been equilibrated in a mantle assemblage where garnet was not present and with garnet, respectively. Symbols as in Fig. 2.

roxenes are chemically similar to those that occur as megacrysts in worldwide alkali basaltic-like magmas (e.g. Irving 1974, Schulze 1987, Nasir 1995).

Group II: aluminian chromian enstatite $[3.04<$ $\left.\mathrm{Al}_{2} \mathrm{O}_{3}<3.34 ; \mathrm{Cr}_{2} \mathrm{O}_{3}=0.90 ; \mathrm{Mg}_{\text {opx }}=0.91\right]$ that exhibits subeuhedral shape. Chemical compositions exclude any genetic links with the Group I orthopyroxenes and suggest a peridotitic derivation (cf. Haggerty 1995).

\section{GARNETS}

Abundant in the Janjão and Pandolfo diatremes, but scarce in the Lambedor occurrence, garnets are found as small euhedral to subeuhedral crystals, usually ruby purple in color, ranging between 1 and $3 \mathrm{~mm}$ in diameter, characterized by clean surfaces, lacking of alteration and/or inclusions of other minerals and absence of keliphytic rims. They present a chromium-pyrope affinity $\left(\mathrm{Alm}_{11-15.5} \mathrm{And}_{1.3-4.3} \mathrm{Gr}_{3.2-7.6} \mathrm{Py}_{70.6-74.8} \mathrm{Sp}_{0.4-0.9} \mathrm{Uv}_{3.7-5.9}\right)$ and show strong similarities with garnets from garnet peridotite xenoliths usually found in kimberlites (Figs. 6A, B). In the $\mathrm{Cr}_{2} \mathrm{O}_{3}$ and $\mathrm{CaO}$ vs. $\mathrm{Mg}_{\text {grt }}$ diagram (not shown), $\mathrm{CaO}$ displays a poor positive correlation $(\mathrm{r}=0.73$; Janjão diatreme: $r=0.87$, whereas the other major elements are strongly scattered.

All the analyzed garnets belong to the G9 lherzolitic group of Dawson and Stephens (1975). The lherzolitic nature of these minerals is also confirmed by the classification scheme proposed by Grutter et al. (2004), which is a revised version of the classical Dawson and 


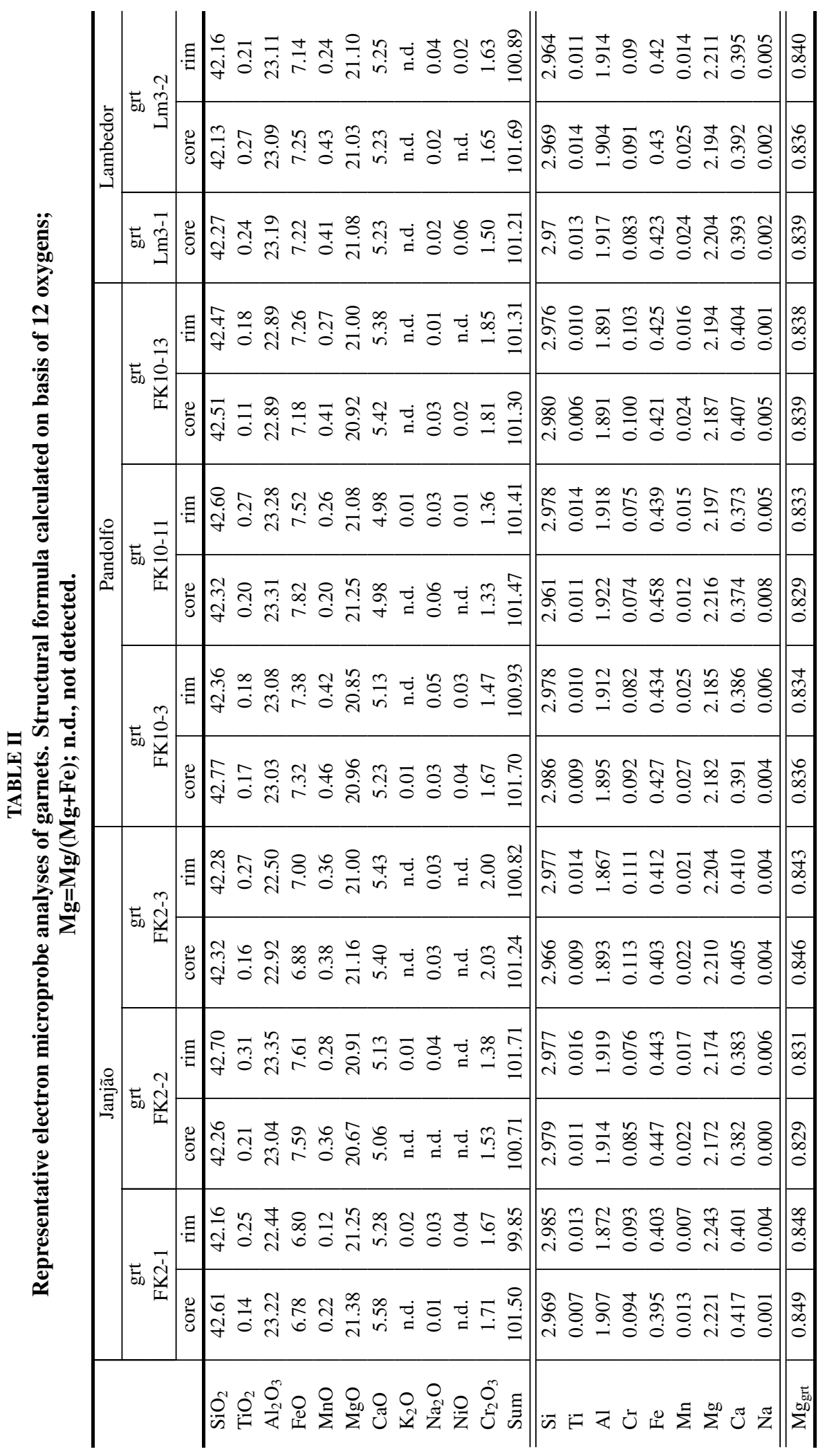


Stephens (1975) method $\left[1.33<\mathrm{Cr}_{2} \mathrm{O}_{3}<2.17 ; 0.81<\right.$ MGNUM $<0.85 ; 4.5<$ CA_INT $<4.96$, where MGNUM $=[(\mathrm{MgO} / 40.3) /(\mathrm{MgO} / 40.3)+(\mathrm{FeO} / 71,85)]$ and CA_INT $=\left[3.375+\left(0.25 * \mathrm{Cr}_{2} \mathrm{O}_{3}\right)\right]$.

Although in the $\mathrm{Cr}_{2} \mathrm{O}_{3}$ vs. $\mathrm{CaO}$ diagram (Fig. 6A; cf. Gurney and Zweistra 1995) the minerals fall in the lherzolite field, they show positive trend that differs from that for the common "lherzolite trend" (Sobolev et al. 1973). The latter lies parallel to the boundary between harzburgitic and lherzolitic domains and it is characterized by a strong enrichment of chromium with calcium, which is considered to be as typical of garnet coexisting with both ortho- and clinopyroxene. The trend outlined by the Lages minerals lies sub-parallel, with lower $\mathrm{Cr}$ contents, to that recognized in some lherzolitic garnets from Jericho, Drybones Bay and Buffalo Hills kimberlites (Slave Craton, Canada: Kopylova et al. 1999, Carbno and Canil 2002, Hood and McCandless 2004), which is believed to be indicative of garnets derived from spinel+garnet peridotites (Kopylova et al. 2000).

\section{Chromian SPINELS AND ILMENITES}

Chromian spinels are found as rounded dark crystals, ranging in size between 1 and $2 \mathrm{~mm}$. All the analyzed grains show similar $\mathrm{MgO}$ and $\mathrm{FeO}$ contents $\left[\mathrm{Mg}_{\mathrm{chr}}=\right.$ $\left.0.57-0.60 ; \mathrm{Mg}_{\text {chr }}=\mathrm{Mg} /\left(\mathrm{Mg}+\mathrm{Fe}^{2+}\right)\right]$. On the contrary, $\mathrm{Al}_{2} \mathrm{O}_{3}$ and $\mathrm{Cr}_{2} \mathrm{O}_{3}$ are more scattered (24.10-29.52 wt\% and 29.94-38.87 wt\%, respectively). Such variations indicate that two groups of chromian spinels could be distinguished: the first one is characterized by higher $\mathrm{Al}$ and lower $\mathrm{Cr}\left[\mathrm{Cr}_{\mathrm{chr}}=0.40-0.43 ; \mathrm{Cr}_{\mathrm{chr}}=\mathrm{Cr} /(\mathrm{Cr}+\mathrm{Al})\right]$, whereas the second by lower $\mathrm{Al}$ and higher $\mathrm{Cr}\left(\mathrm{Cr}_{\text {chr }}\right.$ $=0.52$ ). The grains with lower $\mathrm{Cr}_{\mathrm{chr}}$ probably represent chromian spinels derived from shallow-depth spinel lherzolites where $\mathrm{Al}$ and $\mathrm{Cr}$ contents are mainly controlled by exchange with coexisting pyroxene. On the other hand, grains with higher $\mathrm{Cr}$ values may derive from lherzolites characterized by the presence of low chromian garnet.

Ilmenite occurs as rounded or ellipsoidal discrete monomineralic nodules, ranging in size between 2 and $5 \mathrm{~mm}$. In its thin section it exhibits typical mosaic-textured structures, lack of alteration and/or reaction rims, and no lamellar intergrowths with other mineral phases. All the analyzed specimens have uniform compositions with relatively low $\mathrm{Cr}$ and $\mathrm{Mg}$ contents $\left(\mathrm{Cr}_{2} \mathrm{O}_{3}<0.1\right.$ and $\mathrm{MgO}=3.4-3.5 \mathrm{wt} \%$ ). In general, ilmenites from kimberlites may be derived from both crustal or mantle sources, depending on material sampled by the kimberlitic magma during ascent.

Upper mantle (e.g. kimberlitic or kimberlite related) ilmenites can be either monomineralic (mono- or polycrystalline) or composed by intergrowth with mineral phases such as spinel, rutile or pyroxene (cf. Mitchell 1989). The first group comprises megacrysts and primary groundmass ilmenite. Groundmass ilmenite, genetically linked to the kimberlitic host magma, is characterized by $\mathrm{MgO}$ contents remarkably higher $(\mathrm{MgO}>$ 12\%; Mitchell 1989) than those found in the Lages ilmenite, suggesting that the latter is not related to a kimberlitic magma.

Ilmenite megacrysts show unique major element contents (cf. Wiatt et al. 2004). In the $\mathrm{MgO}-\mathrm{TiO}_{2}$ diagram (not shown) the Lages ilmenites straddle the boundary of ilmenites from kimberlite and non-kimberlite, and are characterized by significant amount of hematite molecule suggesting a relatively high oxygen fugacity condition during crystallization; their $\mathrm{MgO}$ and $\mathrm{Cr}_{2} \mathrm{O}_{3}$ contents are compatible with those of megacrystic ilmenites.

The studied ilmenites contain $\mathrm{MgO}$ and $\mathrm{Cr}_{2} \mathrm{O}_{3}$ contents similar to those of ilmenites from carbonatites (Mitchell 1989). Nevertheless, their low MnO concentrations $(\mathrm{MnO}<0.4 \mathrm{wt} \%)$ and absence in the Lages carbonatites (Comin-Chiaramonti et al. 2002) as well as in the Lages alkaline rocks (L.F. Scheibe, unpublished data, Traversa et al. 1994), do not support this hypothesis. Moreover, ilmenite is not found in the Lages alkaline rocks (L.F. Scheibe, unpublished data, Traversa et al. 1994).

\section{Trace Elements AND REE Composition OF CLINOPYROXENES}

REE and trace element contents of Lages clinopyroxenes are listed in Table IV. All analyzed minerals are LREE enriched (Figs. 7A, B) and display convexupward normalized patterns. $(\mathrm{La} / \mathrm{Yb})_{\mathrm{n}}$ and $(\mathrm{La} / \mathrm{Sm})_{\mathrm{n}}$ are in the ranges 4.49-5.53 and 0.87-0.82, respectively, for the clinopyroxenes from peridotites, and 4.58-6.93 and 0.86-1.19 for the clinopyroxene megacrysts. The clinopyroxenes are characterized by REE patterns similar 

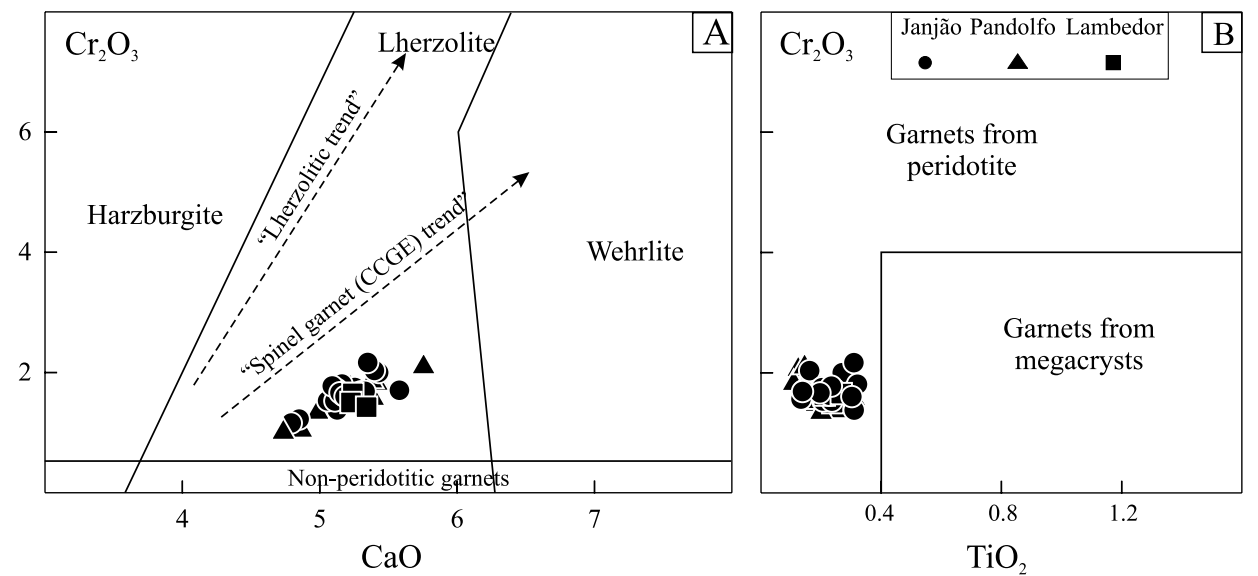

Fig. 6 - A) Variation of $\mathrm{CaO}$ vs. $\mathrm{Cr}_{2} \mathrm{O}_{3}$ for garnets from the Janjão and Pandolfo diatremes. Boundaries between harzburgitic, lherzolitic and non-peridotitic garnets and between lherzolitic and wehrlitic domains are from Gurney and Zweistra (1995) and from Sobolev et al. (1973), respectively. Spinel garnet (CCGE) trend is after Kopylova et al. (2000). B) Variation of $\mathrm{Cr}_{2} \mathrm{O}_{3}$ vs. $\mathrm{TiO}_{2}$ for garnets from the Janjão, Pandolfo and Lambedor diatremes. Boundary between peridotitic and megacrystic domains are from Schulze (2003).

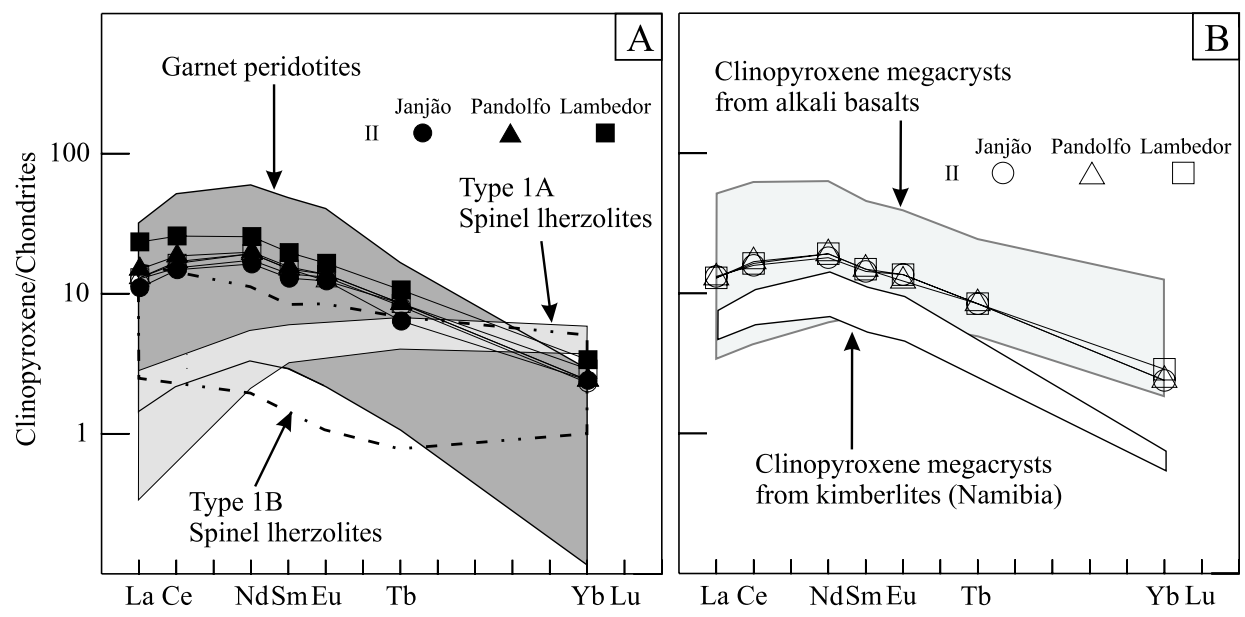

Fig. 7 - REE concentrations in clinopyroxenes from the Janjão, Pandolfo and Lambedor diatremes normalized to chondrite (Boynton 1984). A) Garnet peridotite field after Shimizu (1975), Ehremberg (1982), Ionov et al. (1993), Qi et al. (1995), Roden and Shimizu (2000), Schmidberger and Francis (2001) and Grégoire et al. (2003); Type 1A and 1B spinel peridotite fields after Kempton (1987). Megacrysts from Namibia field after Davies et al. (2001). B) Field of clinopyroxenes from alkali basaltic-like magmas (cf. Fig. 2B) after Irving and Frey (1984), Liotard et al. (1988), Dobosi and Jenner (1999), Shaw and Eyzaguirre (2000), Rankenburg et al. (2004) and Akinin et al. (2005).

to those of clinopyroxenes in equilibrium with garnet (Shimizu 1975, Ehremberg 1982, Menzies et al. 1987, Ionov et al. 1993, Qi et al 1995, Roden and Shimizu 2000, Schmidberger and Francis 2001, Zhang et al. 2001 and references therein; Grégoire et al. 2003), parallel to the patterns of clinopyroxenes from Namibia (72 Ma; cf. Davies et al. 2001 and Fig. 7A) and overlapping the field of clinopyroxene megacrysts from worldwide alkali basaltic-like magmas (Fig. 7B; data from Irving and Frey 1984, Liotard et al. 1988, Dobosi and Jen- 
TABLE III

Representative electron microprobe analyses of chromites and ilmenites. $\mathrm{Fe}_{2} \mathrm{O}_{3}$ contents calculated using the equation of Finger (1972); $\mathrm{Cr}_{\mathrm{chr}}=\mathrm{Cr} /(\mathrm{Al}+\mathrm{Cr})$; n.d., not detected.

\begin{tabular}{|c|c|c|c|c|c|c|c|c|}
\hline & Janjão & Pandolfo & \multicolumn{6}{|c|}{ Lambedor } \\
\hline & $\begin{array}{c}\text { ilm } \\
\text { Jan2-1 } \\
\text { core }\end{array}$ & $\begin{array}{c}\text { ilm } \\
\text { Pan2-1 } \\
\text { core }\end{array}$ & $\begin{array}{c}\text { ilm } \\
\text { Lm5-1 } \\
\text { core }\end{array}$ & $\begin{array}{c}\text { ilm } \\
\text { Lm5-2 } \\
\text { core }\end{array}$ & $\begin{array}{c}\text { ilm } \\
\text { Lm6-1 } \\
\text { core }\end{array}$ & $\begin{array}{c}\text { chr } \\
\text { Lm-12 } \\
\text { core }\end{array}$ & $\begin{array}{c}\text { chr } \\
\text { Lm-13 } \\
\text { core }\end{array}$ & $\begin{array}{c}\text { chr } \\
\text { Lm-15 } \\
\text { core }\end{array}$ \\
\hline $\mathrm{SiO}_{2}$ & 0.05 & 0.04 & 0.03 & 0.01 & 0.03 & 0.07 & 0.11 & 0.09 \\
\hline $\mathrm{TiO}_{2}$ & 40.58 & 40.68 & 42.59 & 42.69 & 40.91 & 1.68 & 1.51 & 1.77 \\
\hline $\mathrm{Al}_{2} \mathrm{O}_{3}$ & 0.26 & 0.27 & 0.33 & 0.34 & 0.44 & 27.72 & 29.52 & 24.10 \\
\hline $\mathrm{Cr}_{2} \mathrm{O}_{3}$ & n.d. & 0.03 & 0.02 & 0.04 & n.d. & 31.73 & 29.94 & 38.87 \\
\hline $\mathrm{FeO}_{\text {tot }}$ & 52.32 & 51.96 & 51.92 & 51.06 & 52.97 & 24.43 & 24.31 & 23.07 \\
\hline $\mathrm{Fe}_{2} \mathrm{O}_{3}$ & 22.90 & 22.42 & 22.28 & 21.49 & 25.05 & 7.73 & 8.65 & 6.07 \\
\hline $\mathrm{FeO}$ & 31.71 & 31.78 & 31.88 & 31.73 & 30.42 & 17.47 & 16.53 & 17.60 \\
\hline $\mathrm{MnO}$ & 0.41 & 0.41 & 0.33 & 0.39 & 0.34 & 13.35 & 14.20 & 13.34 \\
\hline $\mathrm{MgO}$ & 2.47 & 2.49 & 3.42 & 3.49 & 3.40 & 0.03 & n.d. & n.d. \\
\hline $\mathrm{CaO}$ & 0.02 & n.d. & 0.02 & 0.05 & n.d. & n.d. & n.d. & n.d. \\
\hline $\mathrm{NiO}$ & n.d. & n.d. & 0.02 & 0.01 & 0.09 & 0.15 & 0.16 & 0.20 \\
\hline Sum & 98.40 & 98.11 & 100.92 & 100.22 & 100.68 & 99.92 & 100.62 & 102.04 \\
\hline $\mathrm{MgTiO}_{3}$ & 9.50 & 9.57 & 12.71 & 13.06 & 12.70 & - & - & - \\
\hline $\mathrm{FeTiO}_{3}$ & 68.31 & 68.64 & 66.41 & 66.64 & 63.70 & - & - & - \\
\hline $\mathrm{Fe}_{2} \mathrm{O}_{3}$ & 22.19 & 21.79 & 20.88 & 20.30 & 23.61 & - & - & - \\
\hline $\mathrm{Cr}_{\mathrm{chr}}$ & - & - & - & - & - & 0.434 & 0.405 & 0.520 \\
\hline
\end{tabular}

ner 1999, Shaw and Eyzaguirre 2000, Rankenburg et al. 2004, Akinin et al. 2005). They show some differences in their total REE abundance, but only minor difference in REE fractionation.

In the primitive mantle (Sun and McDonough 1989) normalized diagram (Fig. 8) the clinopyroxenes exhibit similar HFSE trends with general enrichment in all the elements, moderate $\mathrm{Zr}$ negative anomalies, and a discrete anomaly of $\mathrm{Y} . \mathrm{Nb}$ and $\mathrm{Ta}$ are more variable and show strong enrichment in the Janjão clinopyroxenes. LILE display significant variations in both Groups I and II clinopyroxenes: $\mathrm{Rb}$ is depleted, $\mathrm{Ba}$ and $\mathrm{Th}$ are variably enriched; in the clinopyroxene megacrysts of the Lambedor diatreme normalized concentrations are less than one.

\section{DISCUSSION}

\section{The Peridotitic Assemblage}

The clinopyroxenes show REE patterns that strongly suggest the presence of garnet in the source. Presence of both chromium-pyrope garnets derived from lherzolite

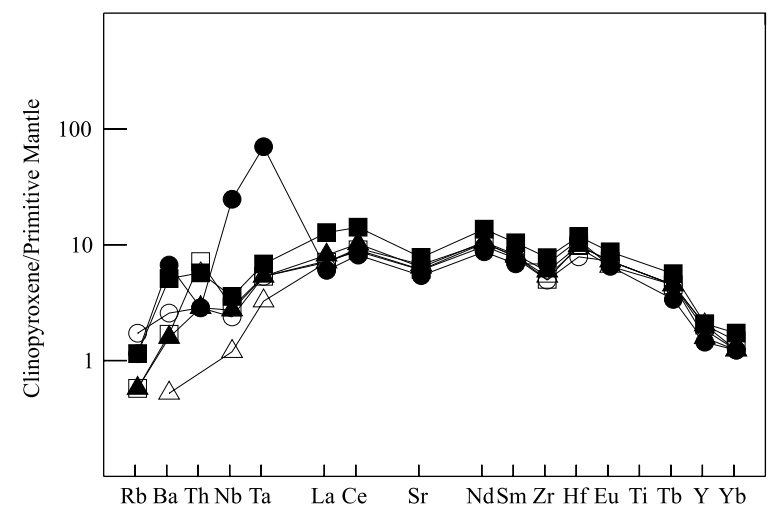

Fig. 8 - Primitive mantle normalized (Sun and McDonough 1989) REE and trace element patterns of clinopyroxenes from the Janjão, Pandolfo and Lambedor diatremes. Symbols as in Fig. 2.

and spinel derived from peridotite indicates that at least part of the clinopyroxenes may be derived from a spinelbearing peridotitic mantle source. Orthopyroxene, clinopyroxene, spinel and garnet of peridotitic origin points to a lherzolitic mantle source. Absence of olivine and scarcity of orthopyroxene should be related to the exten- 
TABLE IV

Trace elements and REE contents of clinopyroxenes. $P$, clinopyroxene from peridotite; $M$, clinopyroxene from megacrysts; n.d., not detected.

\begin{tabular}{l|r|r|r|r|r|r}
\hline \multirow{2}{*}{} & \multicolumn{2}{|c|}{ Janjão } & \multicolumn{2}{|c}{ Lambedor } & \multicolumn{2}{|c}{ Pandolfo } \\
\cline { 2 - 7 } & $\mathrm{M}$ & $\mathrm{P}$ & $\mathrm{M}$ & $\mathrm{P}$ & $\mathrm{M}$ & $\mathrm{P}$ \\
\hline $\mathrm{Li}$ & 1.5 & 1.5 & 1.9 & 2.2 & 1.2 & 1.7 \\
$\mathrm{Be}$ & 0.2 & 0.2 & 0.2 & 0.2 & 0.6 & 2.7 \\
$\mathrm{~V}$ & 234 & 241 & 251 & 209 & 199 & 245 \\
$\mathrm{Co}$ & 34.8 & 35.3 & 34.5 & 31.1 & 34.4 & 38.3 \\
$\mathrm{Cu}$ & 0.6 & 0.5 & 0.3 & 2.2 & 1.9 & 0.4 \\
$\mathrm{Ga}$ & 10.4 & 11.4 & 12.6 & 10.6 & 10.3 & 11.7 \\
$\mathrm{Rb}$ & 0.9 & 0.6 & 0.3 & 0.6 & n.d. & 0.3 \\
$\mathrm{Sr}$ & 105 & 94.1 & 106 & 135 & 117 & 111 \\
$\mathrm{Y}$ & 6.9 & 5.4 & 7.6 & 7.8 & 7.6 & 5.9 \\
$\mathrm{Zr}$ & 45.7 & 62.9 & 46.3 & 71.4 & 49.2 & 54.5 \\
$\mathrm{Nb}$ & 1.4 & 14.5 & 1.7 & 2.1 & 0.7 & 1.6 \\
$\mathrm{Mo}$ & 0.1 & 0.1 & 0.05 & 0.06 & 0.05 & 0.08 \\
$\mathrm{Sn}$ & 0.3 & 0.51 & 0.4 & 0.41 & 0.27 & 0.42 \\
$\mathrm{Te}$ & 0.4 & 0.64 & 0.23 & 0.23 & 0.14 & 0.42 \\
$\mathrm{Ba}$ & 14.8 & 38.5 & 9.7 & 29.4 & 3 & 9.1 \\
$\mathrm{Hf}$ & 2.0 & 2.8 & 2.5 & 3 & 2.4 & 2.5 \\
$\mathrm{Ta}$ & 0.2 & 2.37 & 0.18 & 0.23 & 0.11 & 0.18 \\
$\mathrm{~Pb}$ & 0.3 & 1.5 & 0.4 & 11.1 & 4.74 & 1.04 \\
$\mathrm{Th}$ & 0.2 & 0.2 & 0.5 & 0.4 & n.d. & 0.2 \\
$\mathrm{La}$ & 4.1 & 3.4 & 4 & 7.2 & 4 & 4.6 \\
$\mathrm{Ce}$ & 12.8 & 11.9 & 13.2 & 20.7 & 13.6 & 14.9 \\
$\mathrm{Nd}$ & 10.8 & 9.7 & 11.5 & 15.2 & 11.5 & 11.8 \\
$\mathrm{Sm}$ & 2.8 & 2.5 & 2.9 & 3.8 & 2.9 & 3 \\
$\mathrm{Eu}$ & 1.0 & 0.9 & 1.0 & 1.2 & 0.9 & 1.0 \\
$\mathrm{~Tb}$ & 0.4 & 0.3 & 0.4 & 0.5 & 0.4 & 0.4 \\
$\mathrm{Yb}$ & 0.5 & 0.5 & 0.6 & 0.7 & 0.5 & 0.5 \\
$(\mathrm{La} / \mathrm{Yb})_{\mathrm{n}}$ & 5.53 & 4.58 & 4.49 & 6.93 & 5.39 & 6.20 \\
$\mathrm{La} / \mathrm{Sm})_{\mathrm{n}}$ & 0.92 & 0.86 & 0.87 & 1.19 & 0.87 & 0.96 \\
\hline & & & & & & \\
& & & & &
\end{tabular}

sive weathering and alteration.

Crystallization temperatures of Group II clinopyroxenes were calculated using the enstatite-in-clinopyroxene thermometer of Nimis and Taylor (2000; NT). This geothermometer requires that clinopyroxene should be in equilibrium with orthopyroxene. When clinopyroxene occurs in an orthopyroxene free assemblage, the calculated temperature would represent a minimum value (Read et al. 2004). In this work to minimize calculation errors, only minerals with 1) low $\mathrm{Fe}^{3+} / \mathrm{Fe}^{2+}$ and 2) $\mathrm{Cr}-0.81 \cdot \mathrm{Na} \cdot[\mathrm{Cr} /(\mathrm{Cr}+\mathrm{Al})]>0.003$ (e.g. $\mathrm{Ca}-\mathrm{Cr}$ Tscher- mak's component) were considered (cf. Ramsay 1995, Nimis 1998). The NT temperatures range between 1084 and $1138^{\circ} \mathrm{C}$ at Janjão, 970 and $1106^{\circ} \mathrm{C}$ at Pandolfo, and 1045 and $1129^{\circ} \mathrm{C}$ at Lambedor.

The Lages peridotitic clinopyroxenes show both Al-Cr-Na relationships (Fig. 9; Morris et al. 2002) and high $\mathrm{Al}_{2} \mathrm{O}_{3}$ contents (Haggerty 1995) similar to those of clinopyroxenes of peridotitic nodules found in alkali basaltic-like magmas (e.g. Pali Aike, south Argentina, Kempton 1987, Kempton et al. 1999; Eastern Paraguay, Demarchi et al. 1988; northeastern Brazil, Princivalle et al. 1989, 2000; Vitim volcanic field, Baikal region, Ionov et al. 1993; Burkal river, Siberia, Litasov et al. 2003) than from clinopyroxenes typical of peridotite xenoliths and commonly present in kimberlites (e.g. Kaapwaal craton, Grégoire et al. 2003; Siberian craton, Schmidberger and Francis 1999, 2001).

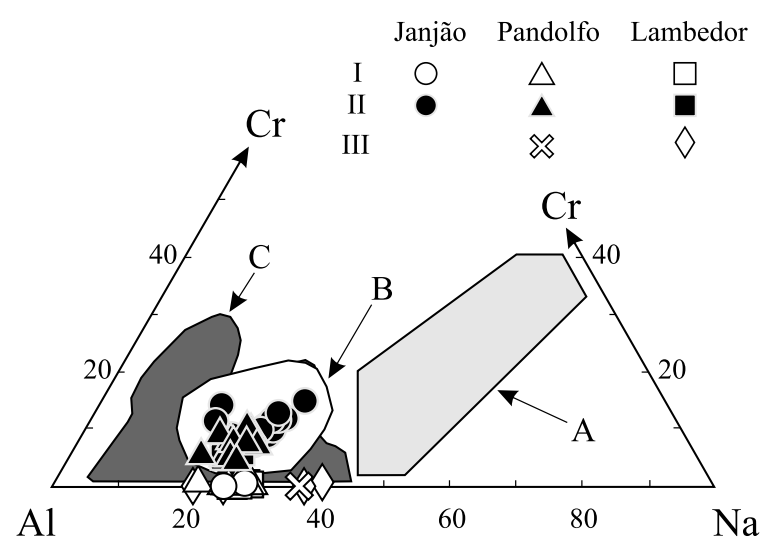

Fig. 9 - Al-Cr-Na ternary diagram for clinopyroxenes from the Janjão, Pandolfo and Lambedor diatremes. A) mantle-equilibrated clinopyroxenes derived from kimberlite; B) clinopyroxenes from non-kimberlitic sources; C) clinopyroxenes equilibrated under crustal conditions (after Morris et al. 2002, modified)

Usually, clinopyroxenes from mantle peridotite sampled by kimberlites, in both garnet and/or spinel facies, have low $\mathrm{Al}_{2} \mathrm{O}_{3}$ but high $\mathrm{Cr}_{2} \mathrm{O}_{3}$ contents. They record a complex history of extensive depletion by melt extraction of the mantle source (e.g. Nixon 1995, Griffin et al. 1999): the high $\mathrm{Al}_{2} \mathrm{O}_{3}$ of the Lages clinopyroxenes may be due inherited from a non-refractory fertile mantle, i.e. rich in "basaltic component". The steep decreasing of $\mathrm{Ti}$ and increasing of $\mathrm{Cr}$ with increasing $\mathrm{Mg}_{\text {cpx }}$ are consistent with depletion process by melt ex- 
traction (Fig. 4). Nevertheless, weak negative trends of $\mathrm{Al}$ and $\mathrm{Ca}$ and scattering of Na suggest that these processes, if any, must have been very limited. Moreover, the absence of any correlation between $\mathrm{Mg}_{\mathrm{cpx}}$ and temperature supports such an assumption.

The $\mathrm{Mg}_{\mathrm{cpx}}-\mathrm{Ti}$ trend in the Fig. 4 can be also explained in terms of pressure variation, as clinopyroxenes from low- to high pressure show decreasing of $\mathrm{TiO}_{2}$ with increasing $\mathrm{Mg}_{\mathrm{cpx}}$, and decreasing of $\left(\mathrm{Ti}+\mathrm{Al}^{\mathrm{IV}}\right)$ with increasing Si (Wass 1979). Nevertheless, it is important to note that variations due to depletion processes and pressure tend to superimpose. Cr variation of the Group II clinopyroxenes can be related to pressure conditions and to the presence of garnet in the original assemblage. With increasing pressure the $\mathrm{Al}^{\mathrm{IV}} / \mathrm{Al}^{\mathrm{VI}}$ ratio of clinopyroxenes decreases (Aoki and Shiba 1973). At high pressure pyrope-rich garnet crystallization removes $\mathrm{Al}^{\mathrm{IV}}$ while $\mathrm{Al}^{\mathrm{IV}}$ remains in the pyroxene, and limits the $\mathrm{Al}_{2} \mathrm{O}_{3}$ content of the coexisting pyroxene and spinel, in which aluminium decreases with increasing pressure (Brey et al. 1990). Conversely, the presence of garnet increases the Cr content in pyroxene (Webb and Wood 1986, Ionov et al. 1993). Therefore, clinopyroxenes coexisting with garnet are characterized by lower $\mathrm{Al}^{\mathrm{IV}} / \mathrm{Cr}$ ratio.

The $\mathrm{Al}^{\mathrm{VI}}$ vs. $\mathrm{Al}^{\mathrm{IV}} / \mathrm{Cr}$ for the Group II clinopyroxenes is illustrated in Fig. 10. The minerals define two different trends characterized, respectively, by lower (trend 1) and higher (trend 2) $\mathrm{Al}^{\mathrm{IV}} / \mathrm{Cr}$ at similar $\mathrm{Al}^{\mathrm{VI}}$. The majority of the clinopyroxenes that define the trend 1 derive from the Janjão diatreme with a few grains from the Pandolfo and Lambedor diatremes. These latter show both the highest calculated $\mathrm{T}$ and $\mathrm{Mg}_{\mathrm{cpx}}$ value, lower $\mathrm{Al}^{\text {tot }}$ and higher $\mathrm{Al}^{\mathrm{VI}}$ at similar $\mathrm{Al}^{\text {tot }}\left(\mathrm{Al}^{\mathrm{tot}}=\mathrm{Al}^{\mathrm{VI}}+\mathrm{Al}^{\mathrm{IV}}\right)$. These phases could be derived from a garnet \pm spinelbearing mantle source. Clinopyroxenes of trend 2 could have been derived from a garnet-free mantle source.

VM1 and VCell of the clinopyroxenes may change as a consequence of melting processes, i.e. increasing temperature (Dal Negro et al. 1984, 1989, Nimis and Ulmer 1998): the triple substitution $\mathrm{Al}^{\mathrm{VI}} \mathrm{Fe}^{2+} \mathrm{Ti}^{4+} \rightarrow$ $\mathrm{Cr}^{3+} \mathrm{Fe}^{3+} \mathrm{Mg}^{2+}$ occurring at the M1 site during melting is responsible for the increasing of VM1 values. Nevertheless, variations in these parameters can also be due to pressure decrease (Princivalle et al. 2000 and references therein). With increasing $\mathrm{Mg}_{\text {cpx }}$ [Fig. $11 ; \mathrm{Mg}_{\mathrm{cpx}}$
$\left.=\mathrm{Mg} /\left(\mathrm{Mg}+\mathrm{Fe}^{2+}\right)\right] \mathrm{VM} 1$ values do not decrease in the Group II clinopyroxenes from Lages diatremes, suggesting that melting processes have not been extensive. It should be noted that in this case $\mathrm{Fe}^{3+}$ was not added, because it remained confined in the M1 position and could not be exchanged between sites M1 and M2.

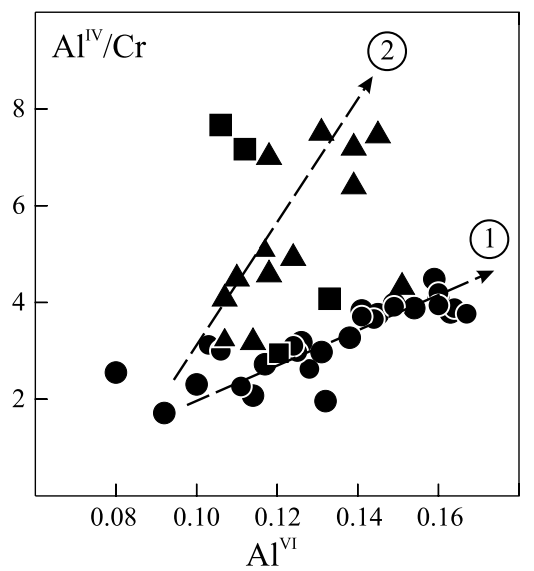

Fig. 10 - Variation in $\mathrm{Al}^{\mathrm{IV}} / \mathrm{Cr}$ vs. $\mathrm{Al}{ }^{\mathrm{VI}}$ for Group II clinopyroxenes from the Janjão, Pandolfo and Lambedor diatremes. 1 and 2: trend of clinopyroxenes thought to have been equilibrated in a mantle assemblage where garnet was not present and with garnet, respectively. Symbols as in Fig. 2.

In Fig. 5 the VCell and VM1 parameters display a distinctive correlation, probably due to pressure variation. Moreover, most of the clinopyroxenes from Janjão and some from Pandolfo and Lambedor diatremes show lower VCell for similar VM1. This behaviour, essentially due to lower tetrahedron volumes, is typical of suites equilibrated at relatively higher pressure (Nimis 1995). It should be noted that the clinopyroxenes with lower VCell at similar VM1 are those that define the trend 1 of Fig. 10.

On the whole, the crystallochemical features of the Group II clinopyroxenes suggest that the upper mantle source has not undergone important depletion by melt extraction and that the Lages peridotitic clinopyroxenes equilibrated at different pressures, i.e. have been derived from different levels of the mantle underlying the Lages alkaline district.

In a non-metasomatized mantle, the major REE carriers are clinopyroxenes (LREE) and garnets (HREE). Consequently, clinopyroxenes in equilibrium with gar- 


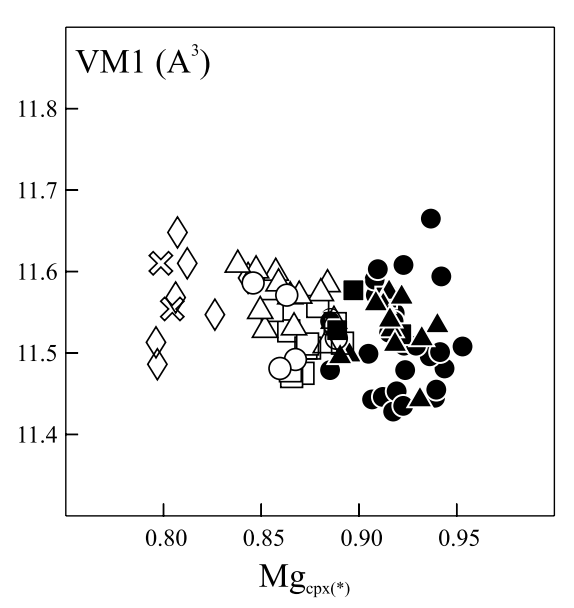

Fig. 11 - Variation in VM1 vs. $\operatorname{Mg}_{\operatorname{cpx}(*)}$ for clinopyroxenes from the Janjão, Pandolfo and Lambedor diatremes. $\operatorname{Mg}_{\mathrm{cpx}(*)}=$ $\mathrm{Mg} /\left(\mathrm{Mg}+\mathrm{Fe}^{2+}\right)$. Symbols as in Fig. 2.

nets typically show upward-convex REE patterns in chondrite-normalized REE diagrams. When garnet is not present in the system (e.g. spinel peridotite), clinopyroxene incorporates HREE and do not show that pattern. Variation in clinopyroxene REE patterns can be also due to depletion processes. After strong melt extraction, the residual clinopyroxene will be depleted in REE and shows positive slope in the chondrite normalized diagrams. REE depletion is often followed by a metasomatic enrichment giving to the clinopyroxene a new REE signature, still characterized by high LREE values (e.g. Grégoire et al. 2003, Carbno and Canil 2002). Fig. 12 displays the variation of $\mathrm{Ce}_{\mathrm{N}}$ vs. $(\mathrm{Ce} / \mathrm{Yb})_{\mathrm{N}}$ of clinopyroxenes. The studied minerals plot in the enriched area that is characterized by high values of both parameters reflecting the fertility of the mantle source and/or the effects of a metasomatic agent. Considering that these phases do show evidence of a depleted protolith, their REE patterns can be only partially attributed to a metasomatic agent, and reflect both the presence of garnet in the original equilibrium assemblage and the fertility of the mantle source.

The studied garnets show chemical signature of garnet from lherzolite. However, although in the $\mathrm{Cr}_{2} \mathrm{O}_{3}$ $\mathrm{CaO}$ space (Fig. 6) they fall in the field of lherzolite, they do not follow the classic "lherzolite trend", typically characterized by a strong correlation between these elements. The "lherzolite trend" is related to the inter-

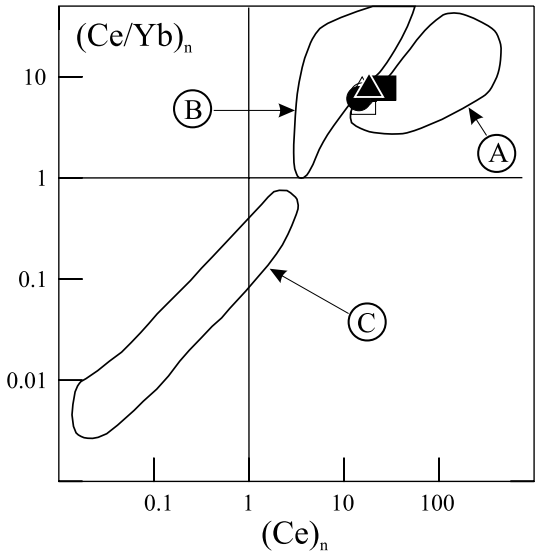

Fig. $12-(\mathrm{Ce} / \mathrm{Yb})_{\mathrm{n}}$ vs. $\mathrm{Ce}_{\mathrm{n}}$ diagram for clinopyroxenes from the Janjão, Pandolfo and Lambedor diatremes. A) field of clinopyroxenes of peridotitic xenoliths from alkali basalts after Wang and Gasparik (2001); B) field of clinopyroxenes of peridotitic xenoliths from kimberlites after Wang and Gasparik (2001) and Grégoire et al. (2003); C) field of clinopyroxenes from abyssal peridotites after Johnson et al. (1990). Symbols as in Fig. 2.

action between $\mathrm{Cr}$ and $\mathrm{Ca}$ in the garnet lattice and, in particular, to the $\mathrm{Cr}-\mathrm{Al}$ ions substitution in the $\mathrm{X}$ structural site that determines the expansion of the site itself, allowing the entry of the larger $\mathrm{Ca}$ ion (cf. Griffin et al. 1999). According to these authors, the position and slope of the "lherzolite trend" are related to tectonic setting and P-T conditions. As shown in Fig. 6, the Lages garnets describe a trend characterized by higher values of the $\mathrm{Ca} / \mathrm{Cr}$ ratio that lies subparallel, with lower $\mathrm{Cr}$ contents, in relation to the CCGE trend of Kopylova et al. (2000). The latter is believed to be indicative of garnets derived from spinel+garnet peridotites in which garnet was in equilibrium with both chromian spinel and clinopyroxene.

At Lages diatremes, the coexistence of chromian spinel and garnet+clinopyroxene suggests that the garnets could mostly derive from spinel+garnet peridotites. Nevertheless, considering that at low $\mathrm{Ca}$ contents the lherzolitic and CCGE trends tend to superimpose, garnets having the lower $\mathrm{Ca}$ contents probably derive from a garnet-bearing mantle source. Moreover, as the CCGE trend is thought to "reflect the presence of relatively fertile rocks at relatively shallow depths" (Kopylova et al. 2000), the low Cr contents that characterize the Lages 
diatreme garnets could reflect both the presence of coexisting clinopyroxenes and the undepleted character of the upper mantle source. The latter assumption is supported by the poor correlation among $\mathrm{Mg}_{\mathrm{grt}}$ and some major elements that suggests that they have not been extensively removed as a result of depletion processes.

Thus, the chemical composition of the studied garnets do not support extensive depletion processes. The $\mathrm{Cr}$ content of garnets is also believed to reflect the $\mathrm{Cr} /(\mathrm{Cr}+\mathrm{Al})$ of the host rock and, therefore, it can be considered as a measure of the depletion of basaltic, i.e. fusible, component (Griffin et al. 1998). The garnets from the Lages diatremes contain $\mathrm{Cr} /(\mathrm{Cr}+\mathrm{Al})$ values substantially lower than those from worldwide depleted lherzolites (e.g. Kaapwaal and Siberian Craton), but similar to those of garnets from fertile peridotites (e.g. Vitim volcanic field, Baikal region; Ionov et al. 1993), indicating a possible weakly depleted mantle source.

On the whole, the crystallochemical data support the layered character of the upper mantle underlying the Lages distremes, i.e. spinel, spinel+garnet and, probably, garnet peridotite facies. Moreover, at the time of the eruption, that mantle should be still rich in "basaltic component", as indicated by the chemical features of the minerals, which exclude large scale depletion via melt extraction.

\section{The Clinopyroxene Megacrysts}

Cr-poor clinopyroxene megacrysts are commonly found in worldwide kimberlites, alnöites and alkali basalts (Schulze 1987), and have been considered both as cognate or non-cognate with the host magma. Nevertheless, all the models agree that such magma was alkaline in character (e.g. Moore and Lock 2001). In the cognate models, the megacrysts would derive from a parental magma closely similar in composition to the host rock. In this view, kimberlite megacrysts would correspond to high pressure phases (45-55 kb; Schulze 1987), equilibrated over a temperature range of $1000-1400^{\circ} \mathrm{C}$ (e.g. Schulze 1987, Schulze et al. 2001, Mitchell 1989, Hops et al. 1992, Smith et al. 1995).

Moore and Belusova (2005) suggested that the megacrysts would represent small volumes of liquids directly derived from the host kimberlite magma. Moreover, they demonstrated a close link between Cr-poor and Cr-rich megacrysts. The former would represent the early crystallization products of the kimberlite magma, whereas the Cr-poor minerals could have been subsequentely crystallized from a $\mathrm{Cr}$ depleted residual liquid. In contrast, the non-cognate models show that megacrysts should be linked to other primary mantle-derived liquids not kimberlitic in composition. Harte (1983) suggested a derivation from basanitic-like parental magma. Griffin et al. (1989) proposed that they have been crystallized from a proto-kimberlite melt. Hops et al. (1992) and Moore et al. (1992) pointed to links between megacrysts and meimechites, whereas Jones (1987) invoked an alkalic or picritic ocean island basalt-like as parental melt. Finally, according to Davies et al. (2001), the megacrysts would be the products of polybaric fractionation of asthenospheric melts of "basaltic" composition, occurring at the base of the subcontinental lithosphere and later incorporated by the ascending kimberlite-like magma as it ascended.

Group A (Cr-poor Al-rich) megacrysts from alkali basaltic-like magmas are believed to represent near liquidus phases, i.e. phenocrysts, crystallized at high pressure from their host magmas (e.g. Irving and Frey 1984, Schulze 1987, Nasir 1995, Neal 1995, Dobosi and Jenner 1999). This assumption is also supported by high pressure experimental works (e.g. Bultitude and Green 1971, Adam 1990). Alternatively, megacrysts have been considered as fragments of pegmatitic veins that crystallized from different parental magmas over a suitable range of pressure and temperature (e.g. Irving 1974, Bodinier et al. 1987, Righter and Carmichael 1993, Shaw and Eyzaguirre 2000, Akinin et al. 2005).

With respect to clinopyroxenes from kimberlites, the studied Group I clinopyroxenes show higher $\mathrm{Al}_{2} \mathrm{O}_{3}$ and $\mathrm{TiO}_{2}$ contents and $\mathrm{Mg}-\mathrm{Ca}-\mathrm{Fe}$ relation (Fig. 2B) similar to those of clinopyroxenes of the Group A ( $\mathrm{Cr}$-poor Al-rich) megacrysts usually found in worldwide alkali basalts and related rocks (Schulze 1987). Usually, unlike their counterparts in kimberlites, Cr-poor megacrysts from alkali basaltic-like magmas show much less regular variation (Fig. 2B), suggesting derivation from many small batches of different magmas over a range of P-T conditions (Schulze 1987). Clinopyroxene megacrysts from kimberlites with chemical compositions similar to those of the Lages Group I have been found in some 
pipes from Victoria, Australia (cf. Dal Negro et al. 1989).

Chemical compositions discriminate the studied Groups I and II clinopyroxenes, the former showing lower $\mathrm{Mg}_{\mathrm{cpx}}$ and different element compositions and inter-element co-variations (Figs. 2-4), which argue for no genetic relationship between clinopyroxenes of these two groups. In terms of VCell and VM1 (Fig. 5), the clinopyroxene megacrysts are distinct from clinopyroxenes of the Group III, but they tend to overlap with the clinopyroxenes of the Group II that are thought to be equilibrated at lower pressure conditions, which in Fig. 10 define the trend 2 . These data indicate that the clinopyroxene megacrysts, although not genetically associated, could have equilibrated/originated at similar conditions of pressure. The studied clinopyroxene megacrysts display higher VCell values at the same VM1 compared to values for clinopyroxenes from kimberlites (cf. Garrison and Taylor 1980, Hops et al. 1992), indicating lower pressure of equilibration.

Estimation of pressure was obtained using the geobarometer of Nimis and Ulmer (1998) that is based on calculation of structural parameters of clinopyroxenes directly from major oxide microprobe analyses. Assuming that clinopyroxenes have equilibrated in a garnet-free assemblage, the estimated P-values range between 8.68 and $12.22 \mathrm{~kb}$ at Janjão, 7.08 and $12.05 \mathrm{~kb}$ at Pandolfo, and 10.06 and $12.05 \mathrm{~kb}$ at Lambedor. The large pressure interval, ranging between 7.08 and $12.22 \mathrm{~kb}$, indicates non-isobaric conditions of crystallization.

Temperatures were obtained according to the graphical version of the Lindsley (1983) geothermometer (LYN). The technique applies to single clinopyroxene grains. At pressure of $10 \mathrm{~kb}$, the temperatures vary from 1120 to $1250^{\circ} \mathrm{C}$ at Janjão, 1080 to $1200^{\circ} \mathrm{C}$ at Pandolfo and 1150 to $1230^{\circ} \mathrm{C}$ at Lambedor diatremes, with an error of $\pm 50^{\circ} \mathrm{C}$. At $15 \mathrm{~kb}$, the calculated values rise in general about $50^{\circ} \mathrm{C}$. The calculated LYN temperatures positively correlate with $\mathrm{Mg}_{\mathrm{cpx}}$ supporting a derivation from parental magma through fractional crystallization. Considering the $\mathrm{P}$ calculated values, it appears that crystallization occurred over a large range of pressure and temperature.

Group I clinopyroxenes show REE contents and chondrite-normalized patterns (Fig. 7B) that differ from those that caracterize clinopyroxenes of $\mathrm{Cr}$-poor suite from kimberlites (Jones 1987, Davies et al. 2001), but resemble those of clinopyroxene megacrysts from alkali basalts (e.g. Irving and Frey 1984, Liotard et al. 1988, Dobosi and Jenner 1999, Shaw and Eyzaguirre 2000, Rankenburg et al. 2004, Akinin et al. 2005). Moreover, the quite humped REE patterns of Lages diatreme megacrysts are also consistent with equilibrium with rather alkaline primitive melts.

On the whole, from the above discussion, it is possible to conclude that there are not clear evidence supporting a kimberlitic affinity for the Group I megacrysts. Instead the studied clinopyroxenes bear close chemical similarities with clinopyroxenes of worldwide alkali basaltic magmas, and therefore it may be possible to relate the Group I clinopyroxene megacrysts with alkaline rocks of the Lages district.

Therefore, considering the close similarities with analogous phases commonly found in worldwide alkali basaltic-like magmas it appears reasonable to suppose that the Group I clinopyroxene megacrysts could have some links with the alkaline rocks cropping out in the Lages district.

Trace element partitioning coefficients between clinopyroxene and melt can give useful information on the trace element contents of parental magma, considering the relation $[X]_{\text {melt }}=[X]_{\mathrm{cpx}} / \mathrm{D}_{\mathrm{x}}$, being $X$ the element of interest and $\mathrm{D}_{\mathrm{x}}$ the partition coefficient of the $X$ element between clinopyroxene and melt. The REE contents and patterns of hypothetical liquids in equilibrium with the Group I clinopyroxenes were calculated using the partition coefficients of Hart and Dunn (1993). In the Fig. 13 they are compared with the trends of rock-types (olivine melilitite, OM; olivine nefelinite, ON; basanite, BA; minette, MI) outcropping in the Lages district, thought to represent primary liquids equilibrated with upper mantle peridotites (Traversa et al. 1994, 1996). In this figure are also plotted trace element abundance of some minettes (MI) believed to be originated from a relatively fertile clinopyroxene-rich peridotitic source. In general, trace element abundance of the calculated liquids in equilibrium is similar to that of Group I clinopyroxene megacrysts, and REE fit the range of the Lages rocks. Major differences are observed for $\mathrm{Ba}-\mathrm{Nb}$, and only minor ones are indicated for $\mathrm{Y}$ and $\mathrm{Sr}$.

Traversa et al. (1996) demonstrated that at Lages 


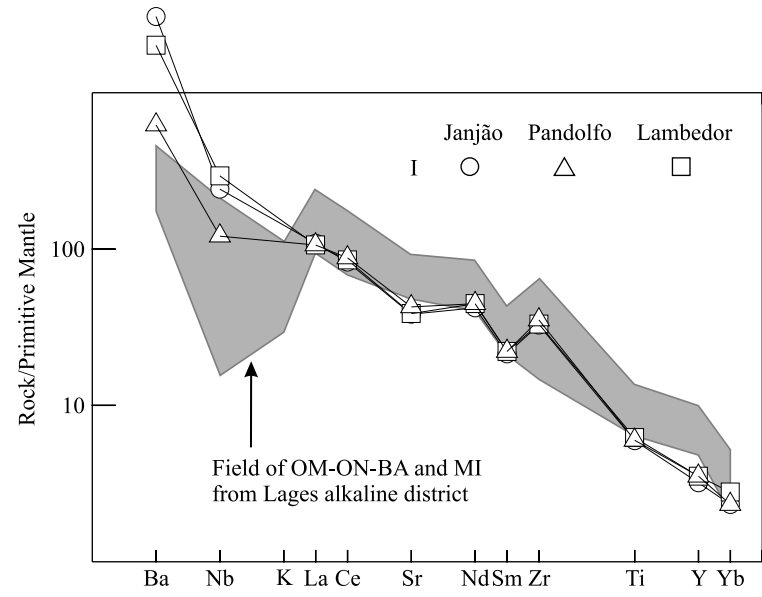

Fig. 13 - Primitive mantle normalized (Sun and McDonough 1989) REE and trace element patterns of the calculated hypothetical liquids equilibrated with the clinopyroxene megacrysts from the Janjão, Pandolfo and Lambedor diatremes compared with Lages silicate rock-types (OM, olivine melililite; ON, olivine nephelinite; BA, basanite; MI, minette; cf. Traversa et al. 1994, Gibson et al. 1995). Liquids were calculated from megacrysts composition using the clinopyroxene-melt partition coefficients for silicate systems of Hart and Dunn (1993).

the differentiated leucocratic phonotephrite and peralkaline phonolite rock-types could have been derived from fractional crystallization processes of basanitic and/or nephelinitic magmas, and excluded any cogenetic relation between olivine melilitites and the more evolved rock-types. Moreover, the strong consistency between $\mathrm{OM}, \mathrm{ON}$ and $\mathrm{BA}$, in terms of $\mathrm{Sr}$ and $\mathrm{Nd}$ isotopic composition and some trace element concentrations, led the authors to consider these rocks as derived from different low degrees of partial melting of a common metasomatized mantle source, having garnet as residual phase. Melting is presumed to have occurred between 24 and $35 \mathrm{~kb}$ pressure. Gibson et al. (1999) also suggested a similar derivation for the sodic alkaline rocks, i.e. olivine melilites and nephelinites outcropping in the area, and interpreted the K-negative anomalies in these rocks as due to phlogopite as residual phase.

Using a distribution coefficient $\mathrm{Kd}=(\mathrm{FeO})_{\mathrm{cpx}}$ $\left.(\mathrm{MgO})_{\text {liq }}\right] /(\mathrm{FeO})_{\text {liq }}(\mathrm{MgO})_{\text {cpx }}$ [in which $(\mathrm{FeO})_{\mathrm{cpx}}$ and $(\mathrm{MgO})_{\mathrm{cpx}}$ represent the mole fraction of $\mathrm{FeO}$ and $\mathrm{MgO}$ in clinopyroxene and all $\mathrm{Fe}$ is taken as $\mathrm{FeO}$ ] of 0,29 (Irving and Frey 1984), it has been calculated the $\mathrm{MgO} / \mathrm{FeO}$ ratio of the hypothetical magma from which the Group I clinopyroxenes could have crystallized. The calculated values range from 0.59 and 0.88 . These ratios are lower tha those of OM, ON, BA and MI, thus indicating derivation from more iron-rich, i.e. more evolved magma. Moreover, the values are higher in comparison with those of the evolved lithotypes (phonotephrites, nepheline syenites, trachyphonolites and peralkaline phonolites) cropping out in the area (Traversa et al. 1994).

The trace element deviation shown by the calculated liquid in equilibrium with the megacrysts (Fig. 13) can be only in part related to evolutionary causes. In fact, although the more evolved Lages lithotypes have $\mathrm{Nb}, \mathrm{Sr}$, and $Y$ contents that partially overlap those of megacrysts, they show very different REE and Ti contents, so discarding the idea that the megacrysts host magma was already highly evolved at the crystallization time of their crystallization. Considering the chemical similarities with the OM, ON, BA and MI, as indicated by the primitive mantle normalized trace element contents of Fig. 13, such enrichments are likely to reflect the action of a metasomatic event.

Altogether these data suggest that the megacrysts represent the high pressure crystallization products of an evolving alkaline magma en route to the surface. In fact, the presence at Lages diatremes of a suite of rocks composed of both primitive and evolved terms linked by fractional crystallization processes, indicates that the Group I megacrysts host magma could have been in equilibrium with more than one specific compositional type of clinopyroxene as it ascended to the surface. It follows that the Group I clinopyroxenes should be considered as phenocrysts, i.e. cognate with their host magma. The magma, at least at the beginning of megacrysts fractionation, was slightly more evolved but still similar, at least in trace elements composition, to the OM, ON, BA and MI ones. Mass balance calculations indicate that the theoretical melt in equilibrium with the Group III clinopyroxenes was characterized, at the time of fractionation, by lower $\mathrm{FeO} / \mathrm{MgO}$ ratio (0.34-0.40), i.e. more evolved magma with respect to the one from which would derive the clinopyroxene megacrysts. In this view, the Group III clinopyroxenes could represent the low-P crystallization clinopyroxene of the same magma that, at higher pressure condition, fractionated the clinopyroxene 
megacrysts. Otherwise, they could be considered as noncognate accidental fragments of a magmatic crustal lithotype with compositional affinity with the mildly evolved alkaline rocks of the Lages district entrained by the megacrysts parental magma during its ascent to the surface, but after megacrysts fractionation. It should be noted that Traversa et al. (1996) point to a crustal magmatic evolution at least for basanite to phonotephrite and nepheline syenite. Unfortunately, the data did not allow tracking down the exact composition of the parental primitive melt of the Group I, and possibly Group III, clinopyroxenes.

\section{The Metasomatic IMPRINT}

The Group I clinopyroxenes show geochemical evidence of a metasomatic imprint and similar trace element patterns of the peridotitic and megacrystic minerals suggest that the metasomatism also affected Group II clinopyroxenes.

Carbonatitic metasomatism may substantially modify the modal mineralogy of a mantle rock or, as in the case of very small melt fraction, it may determine only cryptic but consistent transformations (Rudnick et al. 1993). In the this case changes involve mainly trace elements without any important modifications of major elements content. The lack in the Lages clinopyroxenes of large core-rim major elements variations and reaction structures indicates that the metasomatism was substantially cryptic in nature, i.e. it did not appreciably involve major element contents. In terms of trace elements, $\mathrm{Ti} / \mathrm{Eu}$ and the $(\mathrm{La} / \mathrm{Yb})_{\mathrm{N}}$ of clinopyroxene can be considered as indicators of carbonatite melt metasomatism (Rudnick et al. 1993, Klemme et al. 1995). In this case, the ratios should be $<1500$ and $>3-4$, respectively. At Lages diatremes, $(\mathrm{La} / \mathrm{Yb})_{\mathrm{N}}$ of Group I and II clinopyroxenes range between 4.5 and 5.5 and between 4.6 and 6.9 , respectively, suggesting carbonatite metasomatism. On the other hand, Ti/Eu always greater than 4000 do not support such conclusion.

In order to investigate the influence of a carbonatitic metasomatic agent, it has been calculated the trace elements composition of the theoretical carbonatitic melt in equilibrium with the Lages clinopyroxenes. For this purpose the average partition coefficients of Klemme et al. (1995) were employed, later comparing the calculation results with the trace elements composition of the car- bonatite bodies found in the district (Comin-Chiaramonti et al. 2002). It is important to consider that the outcropping carbonatite rocks could not exactly represent the metasomatic agent responsible for the clinopyroxene trace element modifications. In fact, because of fractional crystallization and continuous interaction with the surrounding rocks during the ascent, the composition of the carbonatite melt could have been partially modified and, thus, could not be identical to that of the primary melt responsible for the metasomatism. Normalized to the primitive mantle (Fig. 14) the calculated trace elements composition of the Groups I and II clinopyroxenes fall in the range of the Lages erupted carbonatites. $\mathrm{Nb}$ enrichment and $\mathrm{Sr}$ and $\mathrm{Y}$ impoverishment of Fig. 13 can be interpreted as reflecting the action of a carbonatitic metasomatic agent. The high Ti/Eu ratios of the Lages clinopyroxenes are likely to reflect the primary high $\mathrm{TiO}_{2}$ content of these minerals, only in part modified by the carbonatitic imprint.

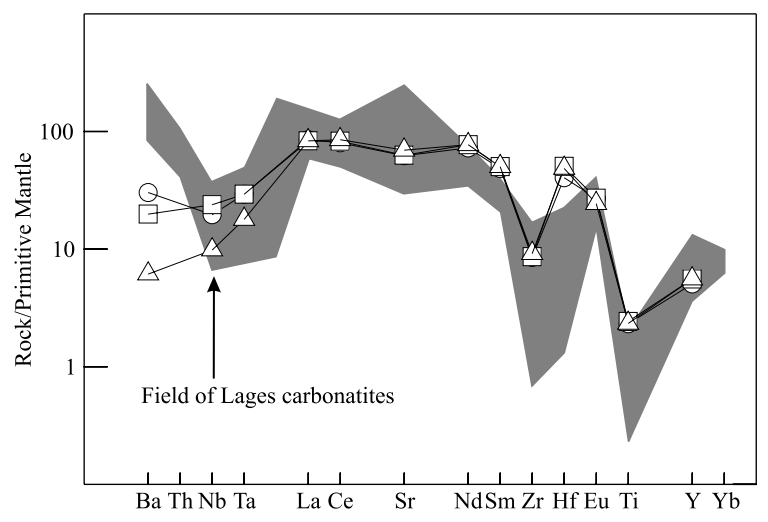

Fig. 14 - Primitive mantle normalized (Sun and McDonough 1989) REE and trace element patterns of the calculated hypothetical liquids equilibrated with the clinopyroxene megacrysts from the Janjão, Pandolfo and Lambedor diatremes compared with the Lages carbonatites (cf. Comin-Chiaramonti et al. 2002). Liquids were calculated from megacrysts composition using the clinopyroxene-melt partition coefficients for carbonate system of Klemme et al. (1995). Symbols as in Fig. 2.

Moreover, Traversa et al. (1996) suggested that the mantle source of the parental rocks from Lages would be highly enriched in strong incompatible elements ( $\mathrm{Ba}$, $\mathrm{Sr}, \mathrm{Th}, \mathrm{U})$ and, in a less extent, in moderately incompatible ones (Ti, $\mathrm{Zr}$, Hf, Y). On the $\mathrm{CaO} / \mathrm{Al}_{2} \mathrm{O}_{3}$ and $\mathrm{Ti} / \mathrm{Eu}$ 
basis, Gibson et al. (1995) proposed that olivine melilitites and melanephelinites derived from sources that experienced carbonatitic imprint, although of different degrees. Kimberlites and some of the Mesozoic alkaline rocks of the APIP have been ascribed to a metasomatized garnet-bearing peridotitic source (Bizzi et al. 1993, Gibson et al. 1995). Finally, potassic and sodic rocks of the western Paraguay magmatic province are also believed to have derived from garnet-bearing sublithospheric mantle source (Comin-Chiaramonti and Gomes 1996).

\section{SUMMARY AND CONCLUSIONS}

The Janjão, Pandolfo and Lambedor diatremes from the Lages alkaline district in the Santa Catarina State, southern Brazil, contain a suite of minerals that has been formed from different sources:

I) aluminian-chromian pyroxenes, pyrope garnets and chromian spinels derived from a peridotite source. They have originated from a fertile mantle which underwent only limited melting. Major element contents of pyroxenes, garnets and chromian spinels and the VCell and VM1 structural parameters of clinopyroxenes suggest that such minerals are disaggregated fragments of spinel, spinel+garnet and garnet facies peridotite. The absence of olivine and the scarcity of orthopyroxene, essential phases in these lithological types, may be due to the tropical weathering that extensively affected the rocks of the region.

II) low-chrome aluminian pyroxenes and orthopyroxenes. They are Cr-poor megacrysts, showing typical features of clinopyroxenes found in worldwide alkali magmas. They are interpreted as high pressure phases (7-12 kb) crystallized from an alkaline evolving magma en route to the surface. Nevertheless, the nature of such magma remains unknown.

III) low-chrome aluminian diopsides of crustal origin. They show close analogies with the clinopyroxenes of the mildly evolved rocks (phonotephrites to nepheline syenites) found in the area.

REE and trace element contents of both peridotitic and clinopyroxene megacrysts reveal a substantially cryptic metasomatic imprint due to the action of carbonatitic fluids.
The chemical features of the studied minerals point to the non-kimberlitic affinity of the diatremes from which they derive. Rather, it is believed that they represent alkaline vents strictly related to the development of the magmatic activity that affected the area during Late Cretaceous times.

A model is here suggested for the generation of the parental magma of the clinopyroxene megacrysts from a garnet facies metasomatized mantle. During its ascent to the surface, this magma incorporated fragments of the surrounding, still fertile, mantle represented by Cr-pyroxenes, pyrope garnets and chromian spinels of peridotitic derivation. Subsequently, presumably at the spinel facies, the magma began to fractionate the megacrysts; the clinopyroxene crystallization proceeded over a range of falling pressure and temperature, and this way the megacrystals can be considered as phenocrysts, i.e. cognate with their host magma. The close compositional similarities between the low-chrome aluminian diopsides of crustal derivation (Group III) found in the diatremes and the clinopyroxenes of the evolved alkaline rocks outcropping in the area possibly suggest that they could represent the low-P crystallization clinopyroxene of the same magma that, at higher pressure condition, fractionated the clinopyroxene megacrysts. Therefore, after megacrysts crystallization, the magma carried this mineral phase on its evolution, at crustal conditions, at least towards alkaline mildly siliceous composition. Otherwise, the clinopyroxenes could also be considered as non-cognate accidental fragments of a magmatic crustal lithotype with compositional affinity with the evolved alkaline rocks of the Lages district entrained by the megacrysts parental magma as it ascended to the surface.

\section{ACKNOWLEDGMENTS}

We are grateful to Profs. E.M. Piccirillo and P. CominChiaramonti for the fundamental suggestions and critical comments during preparation and drafting of this paper. Thanks are due to Fundação de Amparo à Pesquisa do Estado de São Paulo (FAPESP) (Proc. 01/10714-3, CBG) for field assistance. This work has also been supported by funding from MIUR (G. Traversa) and I.G.A.G., "Istituto di Geoscienze e Georisorse", C.N.R.-Roma. 


\section{RESUMO}

Dados químicos de minerais pesados dos diatremas de Lages no sul do Brasil foram estudados com o propósito de caracterizar as fontes das rochas. Três grupos de minerais são reconhecidos: I) piroxênio aluminoso-cromífero, granada piropo e espinélio cromífero, representando fragmentos desagregados de espinélio, espinélio+granada e granada da fácies peridotito; II) piroxênio aluminoso com baixo $\mathrm{Cr}$, correspondendo a megacristais, com as fases de alta pressão (7-12 kb) cristalizadas a partir de magma alcalino em evolução; III) diopsídio aluminoso com baixo $\mathrm{Cr}$ e origem crustal. Clinopiroxênios dos Grupos I e II mostram evidências de enriquecimento metassomático críptico de natureza carbonatítica. Os dados não confirmam a afinidade kimberlítica sugerida para esses diatremas. Ao contrário, eles são interpretados como condutos relacionados ao magmatismo alcalino que afetou a área no Cretáceo Superior. O magma parental alcalino dos megacristais de piroxênio foi originado a partir de um manto metassomatizado na fácies granada que aprisionou fragmentos do ainda fértil manto adjacente. Presumivelmente na fácies espinélio teve início o fracionamento dos megacristais, cuja cristalização se deu em condições de pressão e temperatura decrescentes. As similaridades entre os clinopiroxênios do Grupo III e aqueles dos litotipos mais diferenciados sugere que essa fase mineral foi transportada pelo magma no curso de sua evolução, em condições crustais, para uma composição alcalina mais evoluída. Ainda, uma formação não-cogenética para os clinopiroxênios do Grupo III não pode ser descartada.

Palavras-chave: Brasil, manto, clinopiroxênio, megacristal, metassomatismo.

\section{REFERENCES}

ADAM J. 1990. The geochemistry and experimental petrology of sodic alkaline basalts from Oatlands, Tasmania. J Petrol 31: 1201-1223.

AKinin VV, SoboleV AV, NTAFlos T AND Richter W. 2005. Clinopyroxene megacrysts from Enmelen melanephelinitic volcanoes (Chukchi Peninsula, Russia): application to composition and evolution to mantle melts. Contrib Mineral Petrol 150: 85-101.

Amaral G, Bushee J, Cordani UG, Kawashita K and REYNOLDS JH. 1967. Potassium-Argon ages of alkaline rocks from southern Brazil. Geochim Cosmochim Acta 31: 117-142.

AokI K AND ShibA I. 1973. Pyroxene from lherzolite inclusions of Itinomegata, Japan. Lithos 6: 41-51.
ARaúJo ALN, Carlson RW, Gaspar JC AND Bizzi LA. 2001. Petrology of kamafugites and kimberlites from the Alto Paranaíba Alkaline Province, Minas Gerais, Brazil. Contrib Mineral Petrol 142: 163-177.

Barabino G, Scheibe LF And Traversa G. 2003. Notizie preliminari sui minerali pesanti di alcuni diatremi kimberlitici di Lages (S.C.), Brasile. In: ForUm ITALIANo Scienze Della Terra, 4. Bellaria, Italia. Abstracts.

Berrocal J And Fernandez C. 1996. Seismicity in Paraguay and neighbouring regions. In: COMIN-CHIARAMONTI P AND GOMES CB (Eds), Alkaline magmatism in central-eastern Paraguay. Relationship with coeval magmatism in Brazil, São Paulo: Edusp/Fapesp, p. 57-66.

Bizzi LA, Smith CB, Meyer HOA, Armstrong R And DE WIT MJ. 1993. Mesozoic kimberlites and related rocks in Southwestern São Francisco Craton: a case for local mantle reservoirs and their interaction. In: PROCEEDINGS OF THE INTERNATIONAL KiMBERLITE CONFERENCE, 5, 1991. Araxá, Brazil, p. 156-171.

Bodinier JL, FABRies J, LORAND JP, DOSTAL J AND DEPUZ C. 1987. Geochemistry of amphibole pyroxenite veins from Lherz and Freychinede ultramafic bodies (Ariege French Pyrenees). Bull Mineral 110: 345-358.

BOYNTON WV. 1984. Cosmochemistry of the rare earth element: meteorite studies. In: Henderson P (Ed), Rare Earth Elements geochemistry. Elsevier, p. 63-114.

Brey GP, Kohler T AND Nickel KG. 1990. Geothermometry in four phases lherzolites I. J Petrol 31: 13221352.

Bultitude RJ AND GREen DH. 1971. Experimental study of crystal-liquid relationships at high pressure in olivine nephelinite and basanite compositions. J Petrol 12: 121147.

CARBno GB AND CANIL D. 2002. Mantle structure beneath the southwest Slave craton, Canada: constraints from garnet geochemistry in the Drybones Bay kimberlite. J Petrol 43: 129-142.

Comin-Chiaramonti P And Gomes CB. 1996. Alkaline magmatism in central-eastern Paraguay. Relationship with coeval magmatism in Brazil. São Paulo: Edusp/ Fapesp, 464 p.

Comin-Chiaramonti P And Gomes CB. 2005. Mesozoic to Cenozoic alkaline magmatism in the Brazilian Platform. São Paulo: Edusp/Fapesp, 752 p.

Comin-Chiaramonti P, Gomes CB, Castorina F, Di Censi P, Antonini P, Ruberti E and Scheibe LF. 2002. Geochemistry and geodynamic implications of 
the Anitápolis and Lages alkaline-carbonatite complexes, Santa Catarina State. Rev Bras Geoc 32: 43-58.

Costa VS, Gaspar JC and Pimentel NM. 2003. Peridotite and eclogite xenoliths from the Juína Kimberlite Province, Brazil. In: InTERnATIONAL Kimberlite Conference, 8, 2003. Victoria, Canada. Abstracts.

Dal Negro A, Carbonin S, Domeneghetti C, Molin GM, Cundari A AND PiCcirillo EM. 1984. Crystal chemistry and evolution of the clinopyroxene in a suite of high pressure ultramafic nodules from the Newer Volcanics of Victoria, Australia. Contrib Mineral Petrol 86: 221-229.

Dal Negro A, Manoli S, Secco L and Piccirillo EM. 1989. Megacrystic clinopyroxene from Victoria (Australia): crystal chemical comparison of pyroxenes from high and low pressure regimes. Eur J Mineral 1: 105-121.

Davies GR, Spriggs AJ And Nixon PH. 2001. A noncognate origin for the Gibeon kimberlite megacryst suite, Namibia: implications for the origin of Namibian kimberlites. J Petrol 42: 159-172.

DAWSON JB AND STEPHENS WE. 1975. Statistical classification of garnets from kimberlite and associated xenoliths. J Geology 83: 589-607.

Demarchi G, Comin-Chiaramonti P, De Vito P, Sinigoi S AND CASTillo AMC. 1988. Lherzolitedunite xenoliths from Eastern Paraguay: petrological constraints to mantle metasomatism. In: PICCIRILlo EM AND MELFI AJ (Eds), The Mesozoic flood volcanism on the Paraná basin: petrogenetic and geophysical aspects. IAG-USP, São Paulo, SP, Brazil, p. 207-227.

Dobosi G AND Jenner GA. 1999. Petrologic implications of trace element variation in clinopyroxene megacrysts from the Nograd volcanic province, north Hungary: a study by laser ablation microprobe-inductively coupled plasma-mass spectrometry. Lithos 46: 731-749.

DROOP GTR. 1987. A general equation for estimating $\mathrm{Fe}^{3+}$ concentration in ferromagnesian silicates and oxides from microprobe analyses, using stoichiometric criteria. Min Mag 51: 431-435.

EHREMBERG SN. 1982. Rare earth element geochemistry of garnet lherzolite and megacrystalline nodules from minette of the Colorado Plateau Province. Earth Plan Sci Lett 57: 191-210.

FINGER LW. 1972. The uncertainty in the calculated ferric iron content of electron microprobe analysis. Year Book Carnegie Inst 71: 213-226.
Franz L, BRey GP AND OKRUSCh M. 1996. Steady state geotherm, thermal disturbances, and tectonic development of the lower lithosphere underneath the Gibeon Kimberlite Province, Namibia. Contr Mineral Petrol 126: 181-198.

GARRISON JR AND TAYLOR LA. 1980. Megacrysts and xenoliths in kimberlite, Elliot County, Kentucky: a mantle sample from beneath the Permian Appalachian Plateau. Contr Mineral Petrol 75: 27-42.

Gaspar JC, Araújo Aln, Carlson RW, Sichel SE, SGARBI PB AND DANNI JCM. 2003. Mantle xenoliths and new constraints on the origin of the alkaline ultrapotassic rocks from the Alto Paranaíba Igneous Province, Brazil. In: International Kimberlite ConferENCE, 8. Victoria, Canada. Abstracts.

Gibson SA, Thompson RN, LeOnARdos OH, Dickin AP AND Mitchell JG. 1995. The late Cretaceous impact of the Trindade mantle plume: evidence from largevolume, mafic, potassic magmatism in SE Brazil. J Petrol 36: 189-229.

Gibson SA, Thompson RN, LeOnARdos OH, Dickin AP AND Mitchell JG. 1999. The limited extent of plume-lithosphere interactions during continental floodbasalt genesis: geochemical evidences from Cretaceous magmatism in southern Brazil. Contr Mineral Petr 137: 147-169.

Gomes CB And Comin-Chiaramonti P. 2005. Some notes on the Alto Paranaíba Igneous Province. In: COMin-Chiaramonti P And Gomes CB (Eds), Mesozoic to Cenozoic alkaline magmatism in the Brazilian Platform, São Paulo: Edusp/Fapesp, p. 317-340.

Gomes CB, Ruberti E AND Morbidelli L. 1990. Carbonatite complexes from Brazil: a review. J South Amer Earth Sci 1: 201-234.

GréGoire M, Bell DR AND Le Roex AP. 2003. Garnet lherzolite from the Kaapwaal Craton (South Africa): trace element evidence for a metasomatic history. J Petrol 44 : 629-657.

Grégoire M, Tinguely C, Bell DR and Le Roex AP. 2005. Spinel lherzolite xenoliths from the Premier kimberlite (Kaapvaal craton, South Africa): nature and evolution of the shallow upper mantle beneath the Bushveld complex. Lithos 84: 185-205.

GRIFFIn WL, SMith D, Boyd FR, COUSENS DR, RYAN CG, SIE SH AND SUTER GF. 1989. Trace element zoning in garnets from sheared mantle xenoliths. Geochim Cosmochim Acta, 53: 561-567.

GRIFFIN WL, O'REILly SY, RYAN CG, GAUL O AND IONOV DI. 1998. Secular variation in the composition of 
subcontinental lithospheric mantle: geophysical and geodynamic implications. In: BRAUN ET AL. (Eds), Structure and evolution of the Australian continent. Geodynamics Volume 26, Washington, DC, Am Geophys Union, p. 1-26.

GRIFFIN WL, FISHER NI, FRIEDMAN J, RYAN CG AND O'REILLY SY. 1999. Cr-pyrope garnets in the lithospheric mantle. I. Compositional systematic and relations to tectonic setting. J Petrol 40: 235-256.

Grutter HS, Gurney JJ, Menzies AH And Winter F. 2004. An updated classification scheme for mantlederived garnet, for use with diamond explorers. Lithos 77: 841-857.

GURNEY JJ AND ZWEISTRA P. 1995. The interpretation of the major element compositions of mantle minerals in diamond exploration. J Geochem Explor 53: 293-309.

HAGGERTY SE. 1994. Upper mantle mineralogy. In: INTERNATIONAL SYMPOSIUM ON THE PHYSICS AND CHEMISTRY OF THE UPPER MANTLE, São Paulo, Brazil. Invited Lectures, p. 33-84.

HAGGERTY SE. 1995. Upper mantle mineralogy. J Geodyn 20: $331-364$

HART SR AND DUNN T. 1993. Experimental cpx/melt partitioning of 24 trace elements. Contrib Mineral Petrol 113: $1-8$.

HARTE B. 1983. Mantle peridotite and processes-the kimberlite sample. In: HAWKESWORTH SJ AND MORRY MJ (Eds), Continental basalts and mantle xenoliths, Shiva Publishing, p. 46-91.

Herz N. 1977. Timing of spreading in the South Atlantic: informations from Brazilian alkalic rocks. Geol Soc Amer Bull 88: 101-112.

Hood CTS AND MCCANDLESS TE. 2004. Systematic variations in xenocryst mineral composition at the province scale, Buffalo Hills kimberlites, Alberta, Canada. J Petrol 77: 733-747.

Hops JJ, Gurney JJ and Harte B. 1992. The Jagersfontein Cr-poor megacryst suite - towards a model for megacryst petrogenesis. J Volc Geother Res 50: 143-160.

IONOV DA, ASHKePKov IV, STOSH HG, WitT-EICKSCHEN G AND SECK HA. 1993. Garnet peridotite from the Vitim Volcanic Field, Baikal region: the nature of the garnet-spinel peridotite transition zone in the continental mantle. J Petrol 34: 1141-1175.

IRVING AJ. 1974. Megacrysts from the Newer basalts and other basaltic rocks of southeastern Australia. Geol Soc Am Bull 85:1503-1514.
IRVING AJ AND FREY FA. 1984. Trace element abundances in megacrysts and their host basalts: constraints on partition coefficients and megacryst genesis. Geochim Cosmochim Acta 48: 1201-1221.

Johnson KTM, Dick HJB AND ShimizU N. 1990. Melting in the oceanic upper mantle: ion microprobe study of diopsides in abyssal peridotites. J Geophys Res 95: 2661-2678.

JONES RA. 1987. Strontium and neodymium isotopic and rare earth element evidence for the genesis of megacrysts in kimberlites of Southern Africa. In: NIXON PH (Ed), Mantle xenoliths, Chichester: J. Wiley \& Sons, p. 711724.

KeMPTON PD. 1987. Mineralogic and geochemical evidence for differing styles of metasomatism in spinel-lherzolite xenoliths: enriched mantle source region of basalt. In: Menzies MW and Hawkeswhort CJ (Eds), Mantle metasomatism, New York: Academic Press, p. 45-90.

Kempton PD, Hawkeswort CJ, Lopez Escobar L, Pearson DG and Ware AJ. 1999. Spinel garnet xenoliths from Pali Aike, Part 1: petrography, mineral chemistry and geothermobarometry. In: INTERNAtional Kimberlite Conference, 7, 1999 (Dawson Volume). Cape Town, South Africa. Proceedings, p. 403414.

Klemme S, VAn der LaAn SR, Foley SF and GunTHER D. 1995. Experimentally determined trace and minor element partitioning between clinopyroxene and carbonatite melt under upper mantle conditions. Earth Planet Sci Lett 133: 439-448.

Kopylova MG, Russell JK AND CoOKenboo H. 1999. Petrology of peridotite and pyroxenite xenoliths from the Jericho kimberlite: implication for the thermal state of the mantle beneath the Slave Craton, northern Canada. J Petrol 40: 79-104.

Kopylova MG, Russell JK, Stanley C and CookenBOо H. 2000. Garnet from Cr- and Ca- saturated mantle: implications for diamonds exploration. J Geoch Expl 68: 183-199.

Leonardos OH, Carvalho JB, Tallarico FHB, GibSON S, THOMPSON RN, MEYER HOA AND DICKIN AP. 1993. O xenólito mantélico de Três Ranchos: uma rocha matriz do diamante na Província Magmática Cretácea do Alto Paranaíba, Goiás. In: Simpósio DE GeOlogia De Diamante, 1, 1993. Cuiabá, MT, Brasil. Anais 2: $3-16$.

LindSLEY DH. 1983. Pyroxene thermometry. Am Mineral 68: 477-493. 
LiOTARD JM, BRIOT D AND BIVIN P. 1988. Petrological and geochemical relationships between pyroxene megacrysts and associated alkali-basalts from Massif Central (France). Contrib Miner Petrol 98: 81-90.

Litasov KD, YuRimoto H, Litasov YD AND MALKoVETS VG. 2003. Geochemistry of clinopyroxene from garnet and spinel peridotite of Burkal River (Transbaikal Region, Siberia). Geophys Res Abstract, 5, 04843.

Mantovani MSM, VASCONCEllos ACBC, SHUKOWSKY W AND Milani EJ. 1991. BRUSQUE transect from Atlantic coast to Bolivian border, southern Brazil. In: INTER-UNION COMMISSION LiTHOSPHERE AM GEOPHYS UNION, Global Geosci Transect 4.

Mdludlu S, Mabuza MB, Tainton KM and Sweeney RJ. 2003. A clinopyroxene thermobarometry traverse across Coromandel area, Brazil. In: INTERNATIONAL Kimberlite Conference, 8, 2003. Victoria, Canada. Abstracts.

Menzies MA, Rogers N, Tindle A and HawkesWORTH CJ. 1987. Metasomatic and enrichment processes in lithospheric peridotites, an effect of astenosphere-lithosphere interaction. In: MENZIES MA AND HAWKesworth CJ (Eds), Mantle metasomatism, Academic Press, p. 313-361.

MeYer HOA AND SVISERo DP. 1987. Mantle xenoliths in South America. In: NIXON PH (Ed) Mantle xenoliths, Chichester: J. Wiley \& Sons, p. 85-91.

MeYer HOA AND SVISERo DP. 1991. Limeira and Indaiá intrusions, Minas Gerais. In: INTERNATIONAL KIMBERLite Conference, 5, 1991. Araxá, Brasil. Field Guide Book, p. 49-55.

Meyer HOA, Waring M And Posey EF. 1991. Diamond deposits of the Santo Inácio river and the Vargem intrusions, near Coromandel, Minas Gerais. In: INTERNAtional Kimberlite Conference, 5, 1991. Araxá, mg, Brasil. Field Guide Book, p. 50-57.

Meyer HOA, Garwood BL, SVISERo DP AND SMITH CB. 1993. Alkaline ultrabasic intrusions in western Minas Gerais, Brazil. In: Proceedings of the InterNational Kimberlite Conference, 5, 1991. Araxá, MG, Brazil., p. 140-155.

Mitchell RH. 1989. Kimberlites: mineralogy, geochemistry and petrology, New York: Plenum, 442 p.

MitChell RH. 1995. Kimberlites, orangeites and related rocks, New York: Plenum, $410 \mathrm{p}$.

Mitchell RH and Bergman SC. 1991. Petrology of lamproites, New York, Plenum, 447 p.
Moore AE ANd Belusova E. 2005. Crystallization of Crpoor and Cr-rich megacrysts suite from the host kimberlite magma: implications for mantle structure and the generation of kimberlite magmas. Contrib Mineral Petrol 149: $462-481$.

Moore AE AND Lock NP. 2001. The origin of mantlederived megacrysts and sheared peridotites - evidence from kimberlites in the northern Lesotho - Orange Free State (South Africa) and Botswana pipe clusters. South Afr J Geol 104: 23-38.

Moore RO, GRIFFIN WL, RYAN CG, Cousens DR, SiE SH AND SUTER GF. 1992. Trace element geochemistry of ilmenite megacrysts from the Monastery kimberlite, South Africa. Lithos 29: 1-18.

Morbidelli L, Gomes CB, Beccaluva L, Brotzu P, Conte AM, Ruberti E And Traversa G. 1995. Mineralogical, petrological and geochemical aspects of alkaline and alkaline-carbonatite associations from Brazil. Earth-Sci Rev 39: 135-168.

Morris TF, Sage RP, Ayer JA And Crabtree DC. 2002. A study in clinopyroxene composition: implications for kimberlite exploration. Geoch Expl Env Anal 2: 321-331.

NASIR S. 1995. Cr-poor megacrysts from the Shamah volcanic field, northwestern part of the Arabian Plate. South Afr J Geol 21: 349-357.

NEAL CR. 1995. The relationship between megacrysts and their host magma and identification of the mantle source region. EOS Trans 76: P664.

NiMIS P. 1995. Clinopyroxene from plagioclase peridotites (Zabargad Island, Red Sea) and comparison between highand low-pressure mantle clinopyroxenes. Miner Petrol 53: 49-61.

Nimis P. 1998. Evaluation of diamond potential from the composition of peridotitic chromian diopside. Eur J Mineral 10: 505-519.

Nimis P AND TAYLOR WR. 2000. Single pyroxene thermobarometry for garnet peridotite. Part I: calibration and testing for Cr-in-Cpx barometer and an enstatite-in-Cpx thermother. Contrib Mineral Petrol 139: 541-554.

Nimis P AND Ulmer P. 1998. Clinopyroxene geobarometry of magmatic rocks Part 1: an expanded structural geobarometer for anhydrous and hydrous, basic and ultrabasic systems. Contrib Mineral Petrol 133: 122-135.

NiXON PH. 1995. A review of mantle xenoliths and their role in diamond exploration. J Geodyn 20: 305-329.

PAIVA G. 1933. Geologia do município de Lages, Santa Catarina. Serv Geol Mineral Agric Bol 69, 23 p. 
Piccirillo EM ANd Melfi AJ. 1988. The Mesozoic flood volcanism from the Paraná basin (Brazil): petrogenetic and geophysical aspects. IAG-USP, São Paulo, sp. Brazil, $600 \mathrm{p}$.

Princivalle F, Secco L And Demarchi G. 1989. Crystal chemistry of clinopyroxene series in ultramafic xenoliths from northeastern Brazil. Contrib Mineral Petrol 101: 131-135.

Princivalle F, Salviulo G, Marzoli A, Tirone M AND NYOBE JB. 1995. Crystal chemistry of the constituent phases of a spinel-peridotite nodule from Cameroon Volcanic Line (W-Africa). Miner Petrogr Acta 38: 1-8.

Princivalle F, Salviulo G, Marzoli A and PiccirILLO EM. 2000. Clinopyroxene of spinel-peridotite xenoliths from Lake Nji (Cameroon Volcanic Line, W Africa): crystal chemistry and petrological implications. Contrib Mineral Petrol 139: 503-508.

QI Q, TAYlor LA AND ZHOU XM. 1995. Petrology and geochemistry of mantle peridotite xenoliths from SE China. J Petrol 36: 55-79.

RAMSAY RR. 1995. Geochemistry of diamond indicator minerals. University of Western Australia, Perth, Ph.D. Thesis, unpublished.

RANKENBURG K, LASSITER JC AND BREY G. 2004. Origin of megacrysts in volcanic rocks of the Cameroon volcanic chain - constraints on magma genesis and crustal contamination. Contr Mineral Petrol 147: 129-144.

Read G, Grutter H, Winter S, Luckman N, Gaunt F AND Thomsen F. 2004. Stratigraphic relations, kimberlite emplacement and lithospheric thermal evolution, Quiricó Basin, Minas Gerais, Brazil. Lithos 77: 803-818.

Renne P, Ernesto M, Pacca I, Coe R, Glen J, Prevot M AND PERrin M. 1992. The age of Paraná flood volcanism, rifting of Gondwanaland, and the Jurassic-Cretaceous boundary. Science 258: 975-979.

Riccomini C, VelázQuez VF and Gomes CB. 2005. Tectonic controls of the Mesozoic and Cenozoic alkaline magmatism in the central-southeastern Brazilian Platform. In: Comin-Chiaramonti P AND Gomes CB (Eds), Mesozoic to Cenozoic alkaline magmatism in the Brazilian Platform, São Paulo: Edusp/Fapesp, p. 31-56.

Righter K AND CARMichael ISE. 1993. Mega-xenocrysts in alkali olivine basalts: fragments of disrupted mantle assemblage. Am Mineral 78: 1230-1245.

Roden MF AND SHIMIZU N. 2000. Trace element abundances in mantle-derived minerals which bear in compositional complexities in the lithosphere of the Colorado
Plateau. Chem Geol 165: 283-305.

Rudnik RL, McDonough WF And Chappel B. 1993. Carbonatite metasomatism in the Northern Tanzanian mantle: petrography and geochemical characteristics. Earth Planet Sci Lett 114: 463-475.

SCHEIBE LF. 1978. Fazenda Varela carbonatite, Lages, Santa Catarina, Brazil. In: Simpósio InTERNACIONAL DE Carbonatitos, 1, 1978. Poços de Caldas, Brasil. DNPM 19: 137-146.

SCHEIBE LF AND SVISERo DP. 1988. Minerais de origem mantélica em concentrados da diatrema Janjão, Lages, SC. In: Congresso BRASILEIRo DE GEOlogia, 35, 1988. Belém, PA, Brasil. Anais 3: 1326-1338.

SCHEIBE LF, KAWASHita K AND Gomes CB. 1985. Contribuição à geocronologia do complexo alcalino de Lages, SC. In: Simpósio Sul-Brasileiro de Geologia, 2, 1985. Florianópolis, SC, Brasil. Anais, p. 299-307.

Scheibe LF, Furtado SMA, Comin-Chiaramonti P AND GoMES CB. 2005. Cretaceous alkaline magmatism from Santa Catarina state, southern Brazil. In: CominChiaramonti P and Gomes CB (Eds), Mesozoic to Cenozoic alkaline magmatism in the Brazilian Platform. São Paulo: Edusp/Fapesp, p. 523-572.

SCHMIDBERGER SS AND FRANCIS D. 1999. Nature of the mantle roots beneath the North-American craton: mantle xenolith evidence from Somerset Islands kimberlites. Lithos 48: 195-216.

SCHMIDBERGER SS AND FRANCIS D. 2001. Constraints on the trace element composition of the Archean mantle root beneath Somerset Island, Arctic Canada. J Petrol. 42: 1095-1117.

SCHULZE DJ. 1987. Megacrysts from alkaline volcanic rocks. In: NiXON PH (Ed.), Mantle xenoliths, Chichester: J. Wiley \& Sons, p. 433-452.

SCHUlzE DJ. 2003. A Classification scheme for mantle drived garnets in kimberlites: a tool for investigating the mantle and exploring for diamonds. Lithos 71: 195-213.

Schulze DJ, Valley JR, Bell DR and Spicuzza MJ. 2001. Oxygen isotope variations in Cr-poor megacrysts from kimberlites. Geochim Cosmochim Acta 65: 43754384.

SGarbi PBA, Gaspar JC And VAlença JC. 2000. Clinopyroxenes from Brazilian kamafugites. Lithos 53: 101116.

Shaw CSJ AND EYZAGUiRRE J. 2000. Origin of megacrysts in the mafic alkaline lavas of the West Eifel volcanic field, Germany. Lithos 50: 75-95. 
SHIMIZU N. 1975. Rare earth elements in garnet and clinopyroxene from garnet-lherzolite nodules in kimberlites. Earth Plan Sci Lett 25: 26-32.

SMith AD AND Lewis C. 1999. The planet beyond the plume hypothesis. Earth-Sci Rev 48: 135-182.

Smith CB, Gurney JJ, Skinner EM, Clement CM And EBRAHIM N. 1995. Geochemical character of South African kimberlites: a new approach based on isotopic constraints. Trans Geol Soc South Afr 88: 267-280.

Sobolev NV, LaVRentìeV YG, PoKhilenko NP AND Usova NP. 1973. Chrome-rich garnets from the kimberlites of Yakutia and their parageneses. Contrib Mineral Petrol 40: 39-52.

SONOKI IK AND GARDA GM. 1988. Idades K/Ar de rochas alcalinas do Brasil Meridional e Paraguai Oriental: compilação e adaptação às novas constantes de decaimento. Bol IG-USP, Sér Cient 19: 63-87.

Stewart K, Turner S, Kelley S, HaWkesworth C, Kirstein L And Mantovani M. 1996. 3-D ${ }^{40} \mathrm{Ar}$ ${ }^{39}$ Ar geochronology in the Paraná continental flood basalt province. Earth Planet Sci Lett 143: 95-109.

Sun SS And McDonough WF. 1989. Chemical and isotopic systematics of oceanic basalts: implication for mantle composition and processes. In: SAUNDERS AD AND NORRY MS (Eds), Magmatism in the ocean basins. Geol Soc London Spec Publ, p. 331-345.

SVISERO DP. 1995. Distribution and origin of diamonds in Brazil: an overview. J Geodyn 20: 493-514.

SVisero DP, Meyer HOA and Tsai H. 1977. Kimberlite minerals from Vargem (Minas Gerais) and Redondão (Piauí) diatremes, Brazil; and garnet-lherzolite from Redondão. Rev Bras Geoc 7: 1-13.

Svisero DP, Meyer HOA, Haraly HLE and Hasui Y. 1984. A note on the geology of some Brazilian kimberlites. J Geol 92: 331-338.

SVISERo DP, HARALYI NLE AND SCHEIBE LF. 1985. Magnetometria, radiometria e gamaspectometria na diatrema Janjão, Lages, SC. In: Simpósio Sul-Brasileiro DE Geologia, 2, 1985. Florianópolis, SC, Brasil. Anais, p. 261-272.
Thompson RN, Gibson SA, Mitchell JG, Dickin AP, Leonardos OH, Brod JA AND GreENwood JC. 1998. Migrating Cretaceous-Eocene magmatism in the Serra do Mar alkaline province, SE Brazil: melts from the deflected Trinidade mantle plume? J Petrol 39: 1493-1528.

Traversa G, Scheibe LF, Barbieri M, Coltorti M, Conte AM, Garbarino C, Gomes CB, Macciotta G, Morbidelli L ANd Ronca S. 1994. Petrology and mineral chemistry of the alkaline district of Lages, SC, Brazil. Geochim Brasil 8: 179-214.

Traversa G ET AL. 1996. Mantle sources and differentiation of alkaline magmatic suite of Lages, SC, Brazil. Eur J Mineral 8: 193-208.

Turner SP, Regelous M, Kelley S, Hawkesworth CJ AND Mantovani MSM. 1994. Magmatism and continental break-up in South Atlantic. High precision ${ }^{40} \mathrm{Ar}$ ${ }^{39}$ Ar geochronology. Earth Plan Sci Lett 121: 333-348.

Ulbrich HHGJ AND Gomes CB. 1981. Alkaline rocks from continental Brazil. Earth-Sci Rev 17:135-154.

WANG W AND GASPARIK T. 2001. Metasomatic clinopyroxene inclusions in diamond from the Liaoning province, China. Geochim Cosmochim Acta 65: 611-620.

WASS SY. 1979. Multiple origins of clinopyroxenes in alkali basaltic rocks. Lithos 12:115-132.

WeBB S AND Wood BJ. 1986. Spinel-pyroxene-garnet relationship and their dependence on $\mathrm{Cr} / \mathrm{Al}$ ratio. Contr Mineral Petrol 92: 471-480.

Wiatt BA, BAUMgartner M, ANCKAR E AND GRUTter H. 2004. Compositional classification of kimberlitic and non-kimberlitic ilmenite. Lithos 72: 819-840.

Zhang HF, Sun M, Lu FX, Zhou XH, Zhou MF, LiU YS AND ZHANG GH. 2001. Geochemical significance of a garnet lherzolite from the Dahongshan kimberlite, Yangtze Craton, southern China. Geoch J 35: 315-331. 